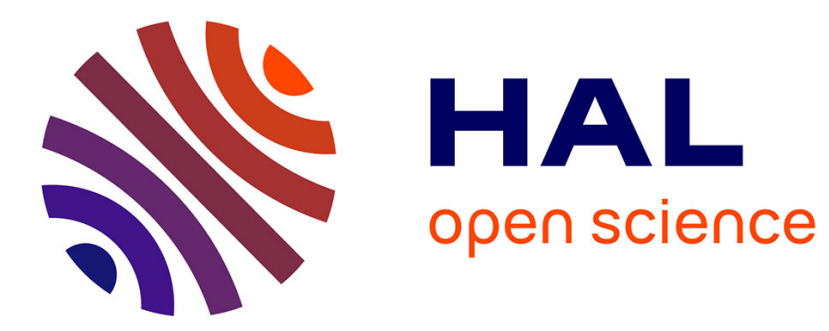

\title{
Geochemistry of Mauritius and the origin of rejuvenescent volcanism on oceanic island volcanoes
}

Debajyoti Paul, William M. White, Janne Blichert-Toft

\section{To cite this version:}

Debajyoti Paul, William M. White, Janne Blichert-Toft. Geochemistry of Mauritius and the origin of rejuvenescent volcanism on oceanic island volcanoes. Geochemistry, Geophysics, Geosystems, 2005, 6, pp.Q06007. 10.1029/2004GC000883 . hal-00102117

\section{HAL Id: hal-00102117 https://hal.science/hal-00102117}

Submitted on 13 Feb 2021

HAL is a multi-disciplinary open access archive for the deposit and dissemination of scientific research documents, whether they are published or not. The documents may come from teaching and research institutions in France or abroad, or from public or private research centers.
L'archive ouverte pluridisciplinaire HAL, est destinée au dépôt et à la diffusion de documents scientifiques de niveau recherche, publiés ou non, émanant des établissements d'enseignement et de recherche français ou étrangers, des laboratoires publics ou privés. 


\title{
Geochemistry of Mauritius and the origin of rejuvenescent volcanism on oceanic island volcanoes
}

\author{
Debajyoti Paul \\ Department of Earth and Atmospheric Sciences, Cornell University, Snee Hall, Ithaca, New York 14853, USA
}

Now at Department of Earth and Environmental Science, University of Texas San Antonio, 6900 North Loop 1604 West, San Antonio, Texas 78249, USA

\author{
William M. White \\ Department of Earth and Atmospheric Sciences, Cornell University, Snee Hall, Ithaca, New York 14853, USA \\ (white@geology.geo.cornell.edu)

\section{Janne Blichert-Toft} \\ UMR 5570, CNRS, Laboratoire de Sciences de la Terre, Ecole Normale Supérieure de Lyon, 46 Allée d'Italie, \\ F-69364 Lyon Cedex 7, France
}

[1] We report new trace element concentrations and $\mathrm{Sr}, \mathrm{Nd}, \mathrm{Hf}$, and $\mathrm{Pb}$ isotopic ratios for basalts from the three lava series of Mauritius. Older Series lavas, which represent the shield-building phase of Mauritius, are isotopically similar to other lavas produced by the Réunion mantle plume. The Intermediate and Younger Series lavas, erupted after a hiatus of millions of years, have more depleted isotopic signatures than the Older Series. Incompatible element abundances and major element compositions suggest that the extent of melting was greatest for the Older Series, smallest for the Intermediate Series, and intermediate for the Younger Series. Volcanic evolution on Mauritius is thus broadly similar to the Hawaiian pattern, with lavas of the rejuvenescent phase being produced by small degrees of melting of a more depleted source than the shield phase. We propose that both shield and rejuvenescent phase magmas are derived from a lithologically heterogeneous or "plum pudding" mantle plume that consists of pods or veins of low-solidus-temperature material such as eclogite or pyroxenite embedded in peridotite matrix. The plums have a less depleted isotopic signature than the matrix. In the vertical stem of the plume, melting is zoned: at greatest depth, only the plums melt; at intermediate depth, both plums and matrix melt, and at shallowest depth, only the matrix melts. Shield stage magmas are hybrids of melts produced in all three zones. As the plume flattens out against the lithosphere and is dragged downstream of the stem, some melting continues due to buoyant lateral spreading of the plume. In this region, although both plums and matrix are melting, melts produced carry the isotopic signature of the matrix because incompatible elements in the plums were previously stripped during melting in the vertical stem of the plume. The relatively small degree melts produced in the melting tail, which give rise to rejuvenescent stage volcanism, thus carry the isotopic signature of the matrix. From a consideration of thermal and isotopic equilibrium, we judge the scale of heterogeneity to be about $10^{2} \mathrm{~m}$.

Components: 13,894 words, 11 figures, 4 tables, 2 animations.

Keywords: mantle plumes; Mauritius; oceanic island volcanism; posterosional volcanism; rejuvenescent volcanism.

Index Terms: 1065 Geochemistry: Major and trace element geochemistry; 1040 Geochemistry: Radiogenic isotope geochemistry; 8121 Tectonophysics: Dynamics: convection currents, and mantle plumes.

Received 22 November 2004; Revised 25 March 2005; Accepted 21 April 2005; Published 21 June 2005.

Paul, D., W. M. White, and J. Blichert-Toft (2005), Geochemistry of Mauritius and the origin of rejuvenescent volcanism on oceanic island volcanoes, Geochem. Geophys. Geosyst., 6, Q06007, doi:10.1029/2004GC000883. 


\section{Introduction}

[2] The island of Mauritius, located at $57^{\circ} 30^{\prime} \mathrm{E}$ and $20^{\circ} 20^{\prime} \mathrm{S}$ (Figure 1), is $65 \mathrm{~km}$ long and is one of several Indian Ocean volcanic islands: Mauritius, Réunion, and Rodrigues, collectively known as the Mascarene Islands. On the basis of eruption ages, Mauritius can be divided into three distinct volcanic units [Baxter, 1972, 1975, 1976]: Older, Intermediate, and Younger Series suites [Simpson, 1950; McDougall and Chamalaun, 1969].

[3] Older Series lavas comprise the erosional remains of a single large shield volcano that was built above sea level by the extrusion of lavas, mainly between 7.8-6.8 Myr ago. The Older Series can be further subdivided into an early and late shield-building stage [Baxter, 1975]. The earlier lavas are transitional basalts (they can be either hypersthene or nepheline normative, although the former predominate, but they plot on the alkali basalt field on the alkali-silica diagram of MacDonald and Katsura [1964]), that have experienced moderate amounts of low-pressure fractional crystallization [Baxter, 1975]. Subsequent eruptions, which persisted until about 5.5 Ma [McDougall and Chamalaun, 1969; Baxter, 1975], produced hawaiite and mugearite with lesser volumes of basalt and trachyte. After a 2 million year hiatus and extensive erosion of the Older Series shield, small volumes of primitive, olivinephyric alkali basalt, basanite, and nephelinite comprising the Intermediate Series were erupted between 3.5-1.9 Myr ago [McDougall and Chamalaun, 1969; Baxter, 1976]. Although earlier maps [e.g., Baxter, 1975, 1976] show that the remaining exposures of Intermediate Series lavas are restricted only to the SW tip of the island, more recent mapping (Figure 1) shows more extensive outcropping of the Intermediate Series.

[4] The Younger Series lavas comprise predominantly K-poor alkaline olivine basalts with subordinate basanite. Younger Series eruptions are confined to localized vents along a major fissure aligned NNE-SSW, collinear with the Southwest Indian Ridge. The K-Ar radiometric dates suggest an eruption interval from 0.7 to $0.17 \mathrm{Ma}$ [McDougall and Chamalaun, 1969]. Like the Older Series, but unlike the Intermediate Series, the composition of Younger Series lavas shows the effects of lowpressure fractionation of olivine and pyroxene [Baxter, 1976]. Earlier maps showed Younger Series lavas blanketing about three quarters of the island [e.g., Baxter, 1976], but more recent mapping reveals a more restricted, but still extensive, exposure (Figure 1).

[5] Mauritius is thought to be the product of melting of the Réunion mantle plume, which in addition to Réunion and Mauritius, was also responsible for the volcanism that created the Mascarene Plateau, and the Chagos-Laccadive Ridge, and, in its initiating phase, the Deccan Traps of western India [Morgan, 1981; Mahoney et al., 2002]. Réunion consists of two shield volcanoes, Piton des Neiges and Piton de la Fournaise. The shield of Piton des Neiges, constructed from 2.0 to 0.43 Ma [McDougall and Chamalaun, 1969], consists of transitional olivine basalts, called the Oceanite Series by Upton and Wadsworth [1965] and is capped by the olivine basalts, hawaiites, mugearites, and trachytes of the Differentiated Series, which erupted between 0.35 and $0.07 \mathrm{Ma}$ [McDougall and Chamalaun, 1969; Upton and Wadsworth, 1965]. However, Deniel et al. [1992] reported ${ }^{230} \mathrm{Th}^{238} \mathrm{U}$, and ${ }^{14} \mathrm{C}$ age measurements that suggest a period of even younger explosive activity on the eastern flank of Piton des Neiges around 0.05 to $0.02 \mathrm{Myr}$ ago, with evidence of volcanic activity on the western flank until 12,000 years ago. Piton de la Fournaise, which is now in its shield-building stage and among the world's most active volcanoes, has erupted transitional olivine basalts similar in composition to the Oceanite Series of Piton des Neiges for the past 530,000 years [Gillot and Nativel, 1989]. The Intermediate Series of Mauritius is contemporaneous with the early phase of Piton des Neiges, while the Younger Series of Mauritius is contemporaneous with the late stage of Piton des Neiges as well as with the early phase of Piton de la Fournaise.

[6] The volcanic evolution of both Mauritius and Réunion shows both similarities and differences with the classic Hawaiian evolution [MacDonald and Katsura, 1964; McDonald, 1968; Chen and Frey, 1983; West et al., 1987]. In both Réunion and Mauritius, the shield-building stage begins, as it does in Hawaii, with eruption of relatively silicasaturated basalts that have experienced moderate low-pressure fractional crystallization. At the termination of the shield-building phase, highly differentiated lavas come to dominate in both Mauritius and Réunion, as they do in Hawaii. In Hawaii, lavas erupted in the main shield building stage are distinctly tholeiitic, whereas in both Réunion and Mauritius, lavas of this phase are best classed as transitional between tholeiite and alkali basalt. Late stage shield capping lavas in Hawaii 


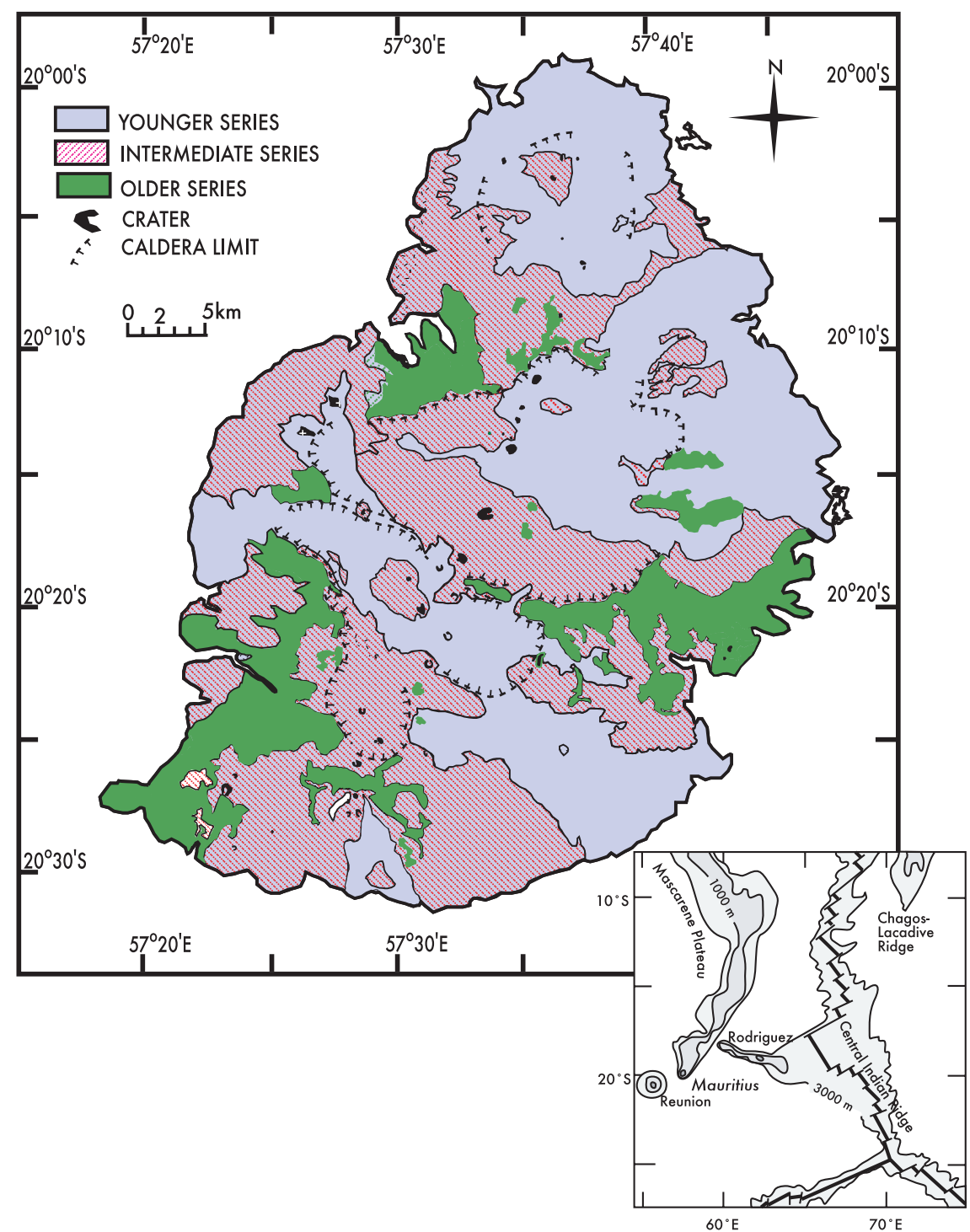

Figure 1. Simplified geologic map of Mauritius modified from the recent 1:50,000 scale geologic map of the Water Resources Unit, Mauritius. This mapping was done in 1999, during a joint Franco-Mauritian project studying the detailed hydrogeologic setting of Mauritius. This map reveals more extensive outcrops of the Intermediate Series and more restricted, but still extensive outcrops of the Younger Series, whereas earlier maps [e.g., Baxter, 1975, 1976; Nohda et al., 2005] show limited exposures of the Intermediate Series (only to the SW tip of the island), and more extensive exposures of the Younger Series covering about three quarters of the island.

are distinctly more alkaline than earlier ones, whereas this is not the case on Piton des Neiges; there are too few well-dated Older Series samples from Mauritius to know if they become alkalic. The Intermediate Series, consisting of highly silicaundersaturated lavas erupted in small volumes following a long hiatus and period of erosion, is clearly analogous to the posterosional series of Hawaii. The Younger Series of Mauritius, which is less alkaline and erupted in larger volumes than the Intermediate Series, has no obvious compositional analog in Hawaii.
[7] Réunion has been the subject of numerous geochemical studies [e.g., Upton and Wadsworth, 1966; McDougall, 1971; Oversby, 1972; Fisk et al., 1988; Albarède et al., 1997; Luais, 2004] while geochemical data on Mauritian basalts are unfortunately scarcer [Norry, 1977; Mahoney et al., 1989; Sheth et al., 2003; Nohda et al., 2005]. We report concentrations for 36 trace elements and $\mathrm{Sr}, \mathrm{Nd}, \mathrm{Pb}$, and $\mathrm{Hf}$ isotopic ratios of 30 basalt samples covering the three different volcanic series of Mauritius. Our objective is to characterize the nature and temporal evolution of the lavas in Mauritius, and to evaluate 
the causes of compositional evolution. In particular, we wished to determine whether the similarities in the geochemical evolution of Hawaiian and Mascarene Islands might have some shared origin.

\section{Analytical Methods}

\subsection{Isotope Ratios}

[8] $\mathrm{Sr}, \mathrm{Nd}$, and $\mathrm{Pb}$ isotope analyses were performed at Cornell University using a FISONS Sector-54 thermal ionization-mass spectrometer. Samples were first leached for approximately 15 minutes in $1 \mathrm{ml}$ of hot $6 \mathrm{~N} \mathrm{HCl}$ and then washed in distilled $\mathrm{H}_{2} \mathrm{O}$ prior to dissolution in order to remove surficial $\mathrm{Sr}$ and $\mathrm{Pb}$ contamination. Subsequent digestion, chemical separation and analysis followed methods previously reported by White et al. [1990, 1993], with one minor modification: for the $\mathrm{Pb}$ purification, which is based on the method described by White and Dupré [1986], we skipped the $2 \mathrm{~N} \mathrm{HCl}$ wash prior to $\mathrm{Pb}$ collection, as it was found that this step resulted in $\sim 40 \% \mathrm{~Pb}$ loss from the columns.

[9] Mass fractionation corrections for $\mathrm{Pb}$ isotope ratios, typically $1.08 \%$ /amu for ${ }^{206} \mathrm{~Pb} /{ }^{204} \mathrm{~Pb}$ and $0.95 \%$ omu for both ${ }^{207} \mathrm{~Pb} /{ }^{204} \mathrm{~Pb}$ and ${ }^{208} \mathrm{~Pb} /{ }^{204} \mathrm{~Pb}$, were determined by repetitive analyses of the NBS$981 \mathrm{~Pb}$ standard assuming true values for the standard of ${ }^{206} \mathrm{~Pb} /{ }^{204} \mathrm{~Pb}=16.937,{ }^{207} \mathrm{~Pb} /{ }^{204} \mathrm{~Pb}=15.493$, and ${ }^{208} \mathrm{~Pb} /{ }^{204} \mathrm{~Pb}=36.705$ [Todt et al., 1996]. The $2 \sigma$ analytical uncertainty, based on reproducibility of NBS-981, is \pm 0.011 for ${ }^{206} \mathrm{~Pb} /{ }^{204} \mathrm{~Pb}, \pm 0.015$ for ${ }^{207} \mathrm{~Pb} /{ }^{204} \mathrm{~Pb}$, and \pm 0.05 for ${ }^{208} \mathrm{~Pb} /{ }^{204} \mathrm{~Pb}$. Standard mass fractionation corrections for $\mathrm{Sr}$ and $\mathrm{Nd}$ isotope ratios were made by normalizing to ${ }^{86} \mathrm{Sr} /{ }^{88} \mathrm{Sr}=$ 0.11940 and ${ }^{146} \mathrm{Nd} /{ }^{144} \mathrm{Nd}=0.72190$, respectively, using an approximate exponential correction. The mean ${ }^{87} \mathrm{Sr} /{ }^{86} \mathrm{Sr}$ ratio of multiple analyses of the NBS-987 Sr standard was 0.71024. The mean ${ }^{143} \mathrm{Nd} /{ }^{144} \mathrm{Nd}$ and ${ }^{145} \mathrm{Nd} /{ }^{144} \mathrm{Nd}$ ratios of multiple analyses of the AMES Nd standard were 0.512182 and 0.348403 , respectively. On the basis of the reproducibility of these standards, the $2 \sigma$ analytical uncertainty is estimated to be \pm 0.00002 for ${ }^{87} \mathrm{Sr} /{ }^{86} \mathrm{Sr}$ and \pm 0.000015 for ${ }^{143} \mathrm{Nd} /{ }^{144} \mathrm{Nd}$. Measured blanks for all elements were trivial.

[10] Hf isotope ratios were determined by multicollector inductively coupled plasma mass spectrometry (MC-ICP-MS; VG Plasma 54) at ENS Lyon using the method described by Blichert-Toft et al. [1997]. The JMC-475 Hf standard was run systematically after every two samples and gave $0.282160 \pm 0.000010(2 \sigma)$ for ${ }^{176} \mathrm{Hf} /{ }^{177} \mathrm{Hf}$, corresponding to an external reproducibility of $0.35 \varepsilon$. ${ }^{176} \mathrm{Hf} /{ }^{177} \mathrm{Hf}$ was normalized for mass fractionation relative to ${ }^{179} \mathrm{Hf} /{ }^{177} \mathrm{Hf}=0.7325$. Hafnium total procedural blanks were less then $25 \mathrm{pg}$.

\subsection{Rare Earth and Other Trace Elements}

[11] Rare earth element analyses were performed using a VG Plasmaquad 2+ ICP-MS at Cornell University using methods described by Cheatham et al. [1993]. Concentrations of the remaining trace elements were determined using a Finnigan Element inductively coupled plasma mass spectrometer (ICP-MS). Chemical preparation for these elements was essentially similar to that described by Cheatham et al. [1993], except that the final solutions were more dilute $(0.025 \%$ total dissolved solids compared with $0.1 \%$ total dissolved solids).

[12] About $25 \mathrm{mg}$ of sample powder along with five external calibration standards (BHVO-2, BEN, BIR-1, AGV-1, and $\mathrm{W}-2$ prepared in parallel with the samples) were weighed into Teflon capsules. An in-house standard (PAL) was analyzed repeatedly to assess the reproducibility of the machine. The samples were digested in hot acid containing 3 $\mathrm{ml}$ of $\mathrm{HNO}_{3}$ and $1.5 \mathrm{ml}$ of HF for 24 hours. After evaporation to dryness, samples were dissolved in dilute $\mathrm{HNO}_{3}$ and the solutions diluted to $100 \mathrm{ml}$ with quartz-distilled water.

[13] Samples were analyzed on the Finnigan Element in two resolution modes: low resolution for $\mathrm{Rb}, \mathrm{Sr}, \mathrm{Y}, \mathrm{Ta}, \mathrm{Pb}, \mathrm{Th}$, and $\mathrm{U}$, and medium resolution for the remaining trace elements. Because of the greater stability of the Finnigan Element compared with the Plasmaquad 2+, the complicated drift correction procedure of Cheatham et al. [1993] was not necessary and concentrations were calculated by simple external calibration. Wash out and sample uptake times were set to $30 \mathrm{sec}$. Typical analysis runs consisted of 1 blank, 5 external calibration standards, 1 in-house standard, and 14 to 18 unknowns. During a single run, all five external calibration standards were run 3 times between unknowns and the average of 3 runs were used during the data reduction. Data reported herein are the means of 2 replicate analyses of each solution run on different days.

\section{Results}

\subsection{Rare Earth and Other Trace Elements}

[14] The rare earth element (REE) results are reported in Table 1. The last two rows in this 
Table 1. Rare Earth Element Analyses of Mauritius Basalts ${ }^{\mathrm{a}}$

\begin{tabular}{|c|c|c|c|c|c|c|c|c|c|c|c|c|c|c|}
\hline & $\mathrm{La}$ & $\mathrm{Ce}$ & $\operatorname{Pr}$ & $\mathrm{Nd}$ & $\mathrm{Sm}$ & $\mathrm{Eu}$ & $\mathrm{Gd}$ & $\mathrm{Tb}$ & Dy & Ho & Er & $\mathrm{Tm}$ & $\mathrm{Yb}$ & $\mathrm{Lu}$ \\
\hline \multicolumn{15}{|c|}{ Younger Series } \\
\hline M-59 & 7.04 & 15.89 & 2.40 & 10.95 & 2.95 & 1.06 & 3.64 & 0.63 & 3.61 & 0.74 & 1.88 & 0.29 & 1.70 & 0.26 \\
\hline M-63 & 12.23 & 23.61 & 3.55 & 15.50 & 3.82 & 1.33 & 4.53 & 0.74 & 4.11 & 0.83 & 2.08 & 0.31 & 1.75 & 0.27 \\
\hline M-79 & 12.70 & 26.37 & 3.74 & 15.93 & 3.77 & 1.38 & 4.14 & 0.68 & 3.81 & 0.76 & 1.93 & 0.29 & 1.74 & 0.26 \\
\hline M-82 & 18.72 & 36.17 & 4.80 & 19.80 & 4.53 & 1.54 & 4.89 & 0.79 & 4.30 & 0.84 & 2.08 & 0.31 & 1.81 & 0.26 \\
\hline M-84 & 9.19 & 18.81 & 2.74 & 12.27 & 3.16 & 1.12 & 3.84 & 0.64 & 3.62 & 0.74 & 1.88 & 0.29 & 1.66 & 0.25 \\
\hline M-86 & 10.05 & 21.95 & 3.19 & 13.96 & 3.55 & 1.22 & 4.06 & 0.69 & 3.88 & 0.78 & 1.98 & 0.30 & 1.79 & 0.27 \\
\hline \multicolumn{15}{|c|}{ Intermediate Series } \\
\hline B-5 & 34.55 & $54.9^{\top}$ & 8.11 & 32.52 & 6.88 & 2.20 & 7.25 & 1.18 & 6.07 & 1.15 & 2.78 & 0.38 & 2.01 & 0.29 \\
\hline B-19 & 16.32 & 32.99 & 4.54 & 19.27 & 4.58 & 1.52 & 5.05 & 0.83 & 4.59 & 0.91 & 2.27 & 0.34 & 1.97 & 0.30 \\
\hline B-21 & 14.75 & 30.03 & 4.15 & 17.57 & 4.19 & 1.41 & 4.65 & 0.77 & 4.24 & 0.83 & 2.07 & 0.31 & 1.82 & 0.27 \\
\hline B-24 & 20.54 & 40.79 & 5.37 & 22.05 & 5.09 & 1.65 & 5.43 & 0.85 & 4.58 & 0.85 & 2.11 & 0.30 & 1.69 & 0.25 \\
\hline B-25 & 19.65 & 35.41 & 5.04 & 21.32 & 5.04 & 1.71 & 5.65 & 0.89 & 4.71 & 0.91 & 2.20 & 0.31 & 1.73 & 0.25 \\
\hline B-27 & 12.29 & 25.35 & 3.62 & 15.50 & 3.79 & 1.29 & 4.25 & 0.71 & 3.91 & 0.77 & 1.91 & 0.29 & 1.66 & 0.24 \\
\hline B-33 & 30.56 & 59.64 & 7.74 & 31.08 & 6.57 & 2.09 & 6.46 & 0.99 & 5.03 & 0.93 & 2.17 & 0.31 & 1.72 & 0.25 \\
\hline $\mathrm{M}-20$ & 22.19 & 38.96 & 5.55 & 23.17 & 5.32 & 1.7 & 5.63 & 0.93 & 4.91 & 0.92 & 2.23 & 0.32 & 1.80 & 0.26 \\
\hline M-23 & 9.03 & 20.1 & 2.8 & & & & & & & & & 0.2 & 1.59 & 0.23 \\
\hline M-25 & 7.78 & & 2.49 & & & & & & & & & 0.3 & 1.75 & 0.27 \\
\hline M-67 & 10.70 & 22.45 & 3.12 & 13.49 & 3.39 & 1.1 & 3.7 & 0.67 & 3.8 & 0.75 & 1.90 & 0.30 & 1.74 & 0.26 \\
\hline M-81 & 22.85 & 46.58 & 5.93 & 24.49 & 5.47 & 1.75 & 5.08 & 0.84 & 4.36 & 0.84 & 2.05 & 0.29 & 1.69 & 0.25 \\
\hline \multicolumn{15}{|c|}{ Older Series } \\
\hline M-4 & 21.27 & 46.44 & 6.06 & 25.96 & 6.02 & 1.91 & 5.76 & 0.96 & 4.80 & 0.94 & 2.18 & 0.31 & 1.74 & 0.25 \\
\hline M-18 & 29.71 & 65.19 & 8.62 & 35.19 & 7.77 & 2.37 & 7.06 & 1.18 & 5.87 & 1.08 & 2.60 & 0.37 & 2.08 & 0.30 \\
\hline M-46 & 25.21 & 55.58 & 7.45 & 31.48 & 7.15 & 2.22 & 6.82 & 1.16 & 5.95 & 1.11 & 2.74 & 0.41 & 2.29 & 0.35 \\
\hline M-50 & 25.62 & 56.72 & 7.60 & 31.83 & 7.22 & 2.26 & 6.89 & 1.16 & 6.20 & 1.17 & 2.91 & 0.44 & 2.54 & 0.37 \\
\hline M-53 & 26.40 & 58.23 & & 32.0 & & & & & & & 2.69 & & 2.23 & 0.32 \\
\hline M-61 & 39.77 & & 10.01 & & & & & & & & & & 2.21 & 0.34 \\
\hline M-69 & 29.15 & 62.32 & 8.00 & 34.36 & 7.87 & 2.42 & 7.21 & 1.17 & 5.91 & 1.13 & 2.59 & 0.36 & 2.04 & 0.30 \\
\hline M-70 & 31.45 & 68.80 & 9.13 & 37.92 & 8.31 & 2.62 & 7.81 & 1.31 & 6.77 & 1.23 & 2.96 & 0.44 & 2.47 & 0.37 \\
\hline M-74 & 20.16 & 44.83 & 6.12 & 26.48 & 6.25 & 2.03 & 6.05 & 1.01 & 5.39 & 1.01 & 2.47 & 0.36 & 2.08 & 0.31 \\
\hline BHVO-1 & 16.08 & 38.80 & 5.70 & 25.91 & 6.37 & 2.07 & 6.47 & 1.06 & 5.54 & 1.04 & 2.51 & 0.36 & 2.06 & 0.30 \\
\hline 1 s.d. & $3.9 \%$ & $3.1 \%$ & $4.8 \%$ & $4.0 \%$ & $4.0 \%$ & $3.4 \%$ & $5.1 \%$ & $2.9 \%$ & $4.0 \%$ & $3.3 \%$ & $4.1 \%$ & $4.8 \%$ & $4.2 \%$ & $2.8 \%$ \\
\hline
\end{tabular}

${ }^{\mathrm{a}}$ All concentrations reported are in parts per million ( $\left.\mathrm{ppm}\right)$.

column give the mean and standard deviation of USGS Standard BHVO-1 analyzed as an unknown with the samples. As can be seen, precision is generally 2 to $3 \%$, but is up to $5 \%$ for Gd and Tm. Figure 2 reveals three distinct chondrite-normalized REE abundance patterns for the three different series. Older Series lavas exhibit parallel REE patterns with a uniform enrichment of the light relative to the heavy rare earths. Both the patterns and absolute abundances are similar to those seen in Réunion lavas [e.g., Fisk et al., 1988], but show somewhat steeper patterns than Hawaiian tholeiites [e.g., Chen and Frey, 1985]. In contrast, all the analyzed Intermediate Series lavas have very similar heavy rare earth element (HREE) abundances, but a range of light rare earth element (LREE) abundances and consequently a range of fractionation between LREE and HREE. Absolute abundances of the LREE in the Intermediate Series range from values similar to those of the Older Series to values significantly lower than that.
Younger Series lavas also display a range of light to heavy rare earth fractionation, although not as great as in the Intermediate Series. On average, they are less LREE-enriched than either the Older or Intermediate Series. Absolute REE concentrations in the Younger Series are generally lower than those in either the Older or Intermediate Series.

[15] Other trace element concentrations are reported in Table 2. Older Series lavas have higher absolute abundances of a number of incompatible elements, notably $\mathrm{Rb}, \mathrm{Sr}, \mathrm{Y}, \mathrm{Zr}$, Hf, and $\mathrm{Pb}$, than the two later series and lower absolute abundances of compatible elements such as $\mathrm{Ni}$ and $\mathrm{Cr}$. $\mathrm{La}, \mathrm{Nb}$, $\mathrm{Ni}$, and $\mathrm{Cr}$ are plotted versus $\mathrm{MgO}$ concentration in Figure 3. Strong correlations between $\mathrm{Ni}$ and $\mathrm{Cr}$ and $\mathrm{MgO}$ are apparent, suggesting their concentrations have been strongly influenced by fractional crystallization. In contrast, $\mathrm{Nb}$ and $\mathrm{La}$ concentrations are essentially uncorrelated with $\mathrm{MgO}$, indi- 


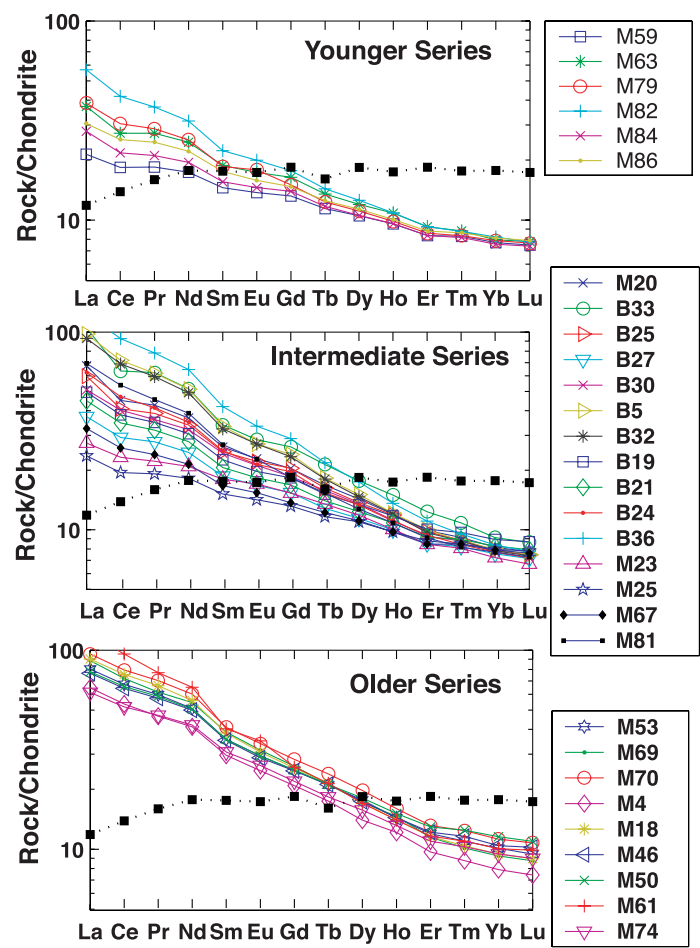

Figure 2. Chondrite-normalized REE abundance patterns for Younger, Intermediate, and Older Series lavas from Mauritius. Dotted lines joining solid squares are chondrite-normalized abundances in NMORB [from Hofmann, 1988]. Chondritic concentrations are based on those of Nakamura [1974].

cating that these, as well as other incompatible element concentrations, primarily reflect other processes or factors such as extent of melting and source heterogeneity. Figure 3 also illustrates the more fractionated character of Older Series lavas compared with the Intermediate and Younger Series, as was pointed out by Baxter [1976].

[16] Figure 4 shows several trace element ratios plotted versus $\mathrm{La}$ concentration. For $\mathrm{Sc} / \mathrm{Yb}$ versus $\mathrm{La}$, all three series define a single correlation, albeit a weak one. For a given La concentration (e.g., $20 \mathrm{ppm}$ ), the Younger and Intermediate Series have higher $\mathrm{La} / \mathrm{Sm}$ and $\mathrm{La} / \mathrm{Yb}$ than the Older Series. In contrast, the Younger and Intermediate Series together form one correlation in plots of $\mathrm{La} / \mathrm{Sm}$, $\mathrm{La} / \mathrm{Yb}$, and $\mathrm{Zr} / \mathrm{Nb}$ versus $\mathrm{La}$, whereas the Older Series forms a separate, generally weaker, correlation. In terms of $\mathrm{La}$ concentrations and $\mathrm{La} / \mathrm{Sm}, \mathrm{La} /$ $\mathrm{Yb}$, and $\mathrm{Sc} / \mathrm{Yb}$ ratios, the Older and Younger Series overlap only slightly, while the Intermediate Series overlaps both other series completely, exhibiting a range of $\mathrm{La}$ concentrations and ratios that essentially encompass the range of the other two series combined. In contrast, $\mathrm{Zr} / \mathrm{Nb}$ ratios of the Older and Younger Series overlap completely, with the Intermediate Series having generally lower $\mathrm{Zr} / \mathrm{Nb}$ ratios.

[17] The ${ }^{233} \mathrm{Th} /{ }^{238} \mathrm{U}$ ratio ( $\kappa$ ) of Mauritius basalts exhibits a distinctive feature of the Réunion mantle plume. Excluding 3 samples (M-59, M-63, and M-46) that have anomalously high $\kappa$ values greater than 5.5 (likely to result from $U$ loss due to posteruptional alteration), the average $\kappa$ of all Mauritius basalts is $4.19 \pm 0.28(1 \sigma)$. This is similar to the time-integrated $\kappa$ value (chondritic) of $4.02 \pm 0.03$ inferred from the radiogenic ${ }^{208} \mathrm{~Pb} /{ }^{206} \mathrm{~Pb}$ ratio [Galer and O'Nions, 1985]. This suggests that Mauritius basalts have similar elemental and time-integrated $\mathrm{Th} / \mathrm{U}$ ratios, a feature characteristic of the Réunion plume and observed in samples from only very few oceanic island basalts (OIB).

\subsection{Isotope Ratios}

[18] $\mathrm{Sr}, \mathrm{Nd}, \mathrm{Pb}$, and $\mathrm{Hf}$ isotope ratios are reported in Table 3. Figure 5 shows that $\mathrm{Sr}, \mathrm{Nd}$, and $\mathrm{Hf}$ isotopic compositions of Mauritius basalts are, for the most part, intermediate between those of Central Indian Ridge MORB (Mid Ocean Ridge Basalt) and Réunion basalts. The three Mauritius series define 3 separate, but somewhat overlapping fields in Sr-NdHf isotope space. Although overall, isotope ratios show the expected correlations, correlations between isotope ratios within individual series are weak. A notable exception is the Older Series, which shows a quite strong correlation between $\mathrm{Hf}$ and $\mathrm{Nd}$ isotope ratios. In contrast, there is almost no correlation between $\mathrm{Nd}$ and $\mathrm{Hf}$ in the Intermediate and Younger Series because Hf isotope ratios are virtually constant within each of these two series. The Intermediate Series is characterized by lower ${ }^{87} \mathrm{Sr} /{ }^{86} \mathrm{Sr}$ and higher $\varepsilon_{\mathrm{Nd}}$ and $\varepsilon_{\mathrm{Hf}}$ than the other series (average: ${ }^{87} \mathrm{Sr} /{ }^{86} \mathrm{Sr}=0.70377, \varepsilon_{\mathrm{Hf}}=10.8$, and $\left.\varepsilon_{\mathrm{Nd}}=5.5\right)$. The Younger Series lavas have $\mathrm{Sr}$ isotopic compositions intermediate between the Older and Intermediate Series, with an average ${ }^{87} \mathrm{Sr} /{ }^{86} \mathrm{Sr}=0.70391$, and generally lower values of $\varepsilon_{\mathrm{Nd}}$, with an average $\varepsilon_{\mathrm{Nd}}=4.9$ and average $\varepsilon_{\mathrm{Hf}}$ of 9.6. The Older Series (average ${ }^{87} \mathrm{Sr} /{ }^{86} \mathrm{Sr}=0.70413$, $\varepsilon_{\mathrm{Hf}}=9.7$ and $\varepsilon_{\mathrm{Nd}}=5$ ) overlaps considerably with the field for Réunion basalts on the $\varepsilon_{\mathrm{Nd}^{-}}{ }^{87} \mathrm{Sr} /{ }^{86} \mathrm{Sr}$ plot; there is less overlap on the $\varepsilon_{\mathrm{Nd}}-\varepsilon_{\mathrm{Hf}}$ plot, but this could simply be a consequence of the very limited amount of Hf isotope data available for Réunion. Mauritius basalts are also broadly similar in $\mathrm{Sr}$ and $\mathrm{Nd}$ isotopic composition to other Indian Ocean islands such as Bouvet, Rodrigues, N. Amsterdam, 


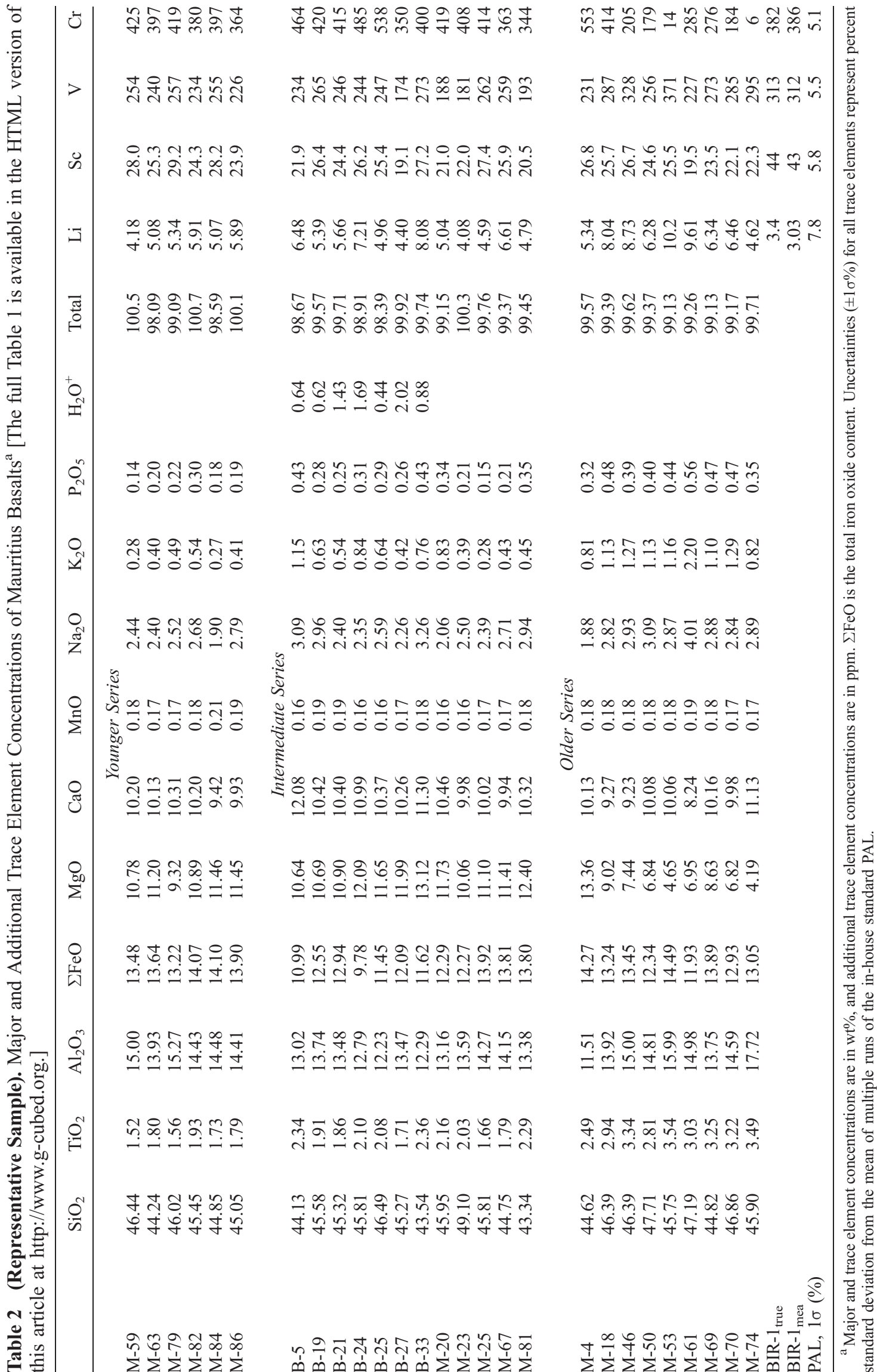



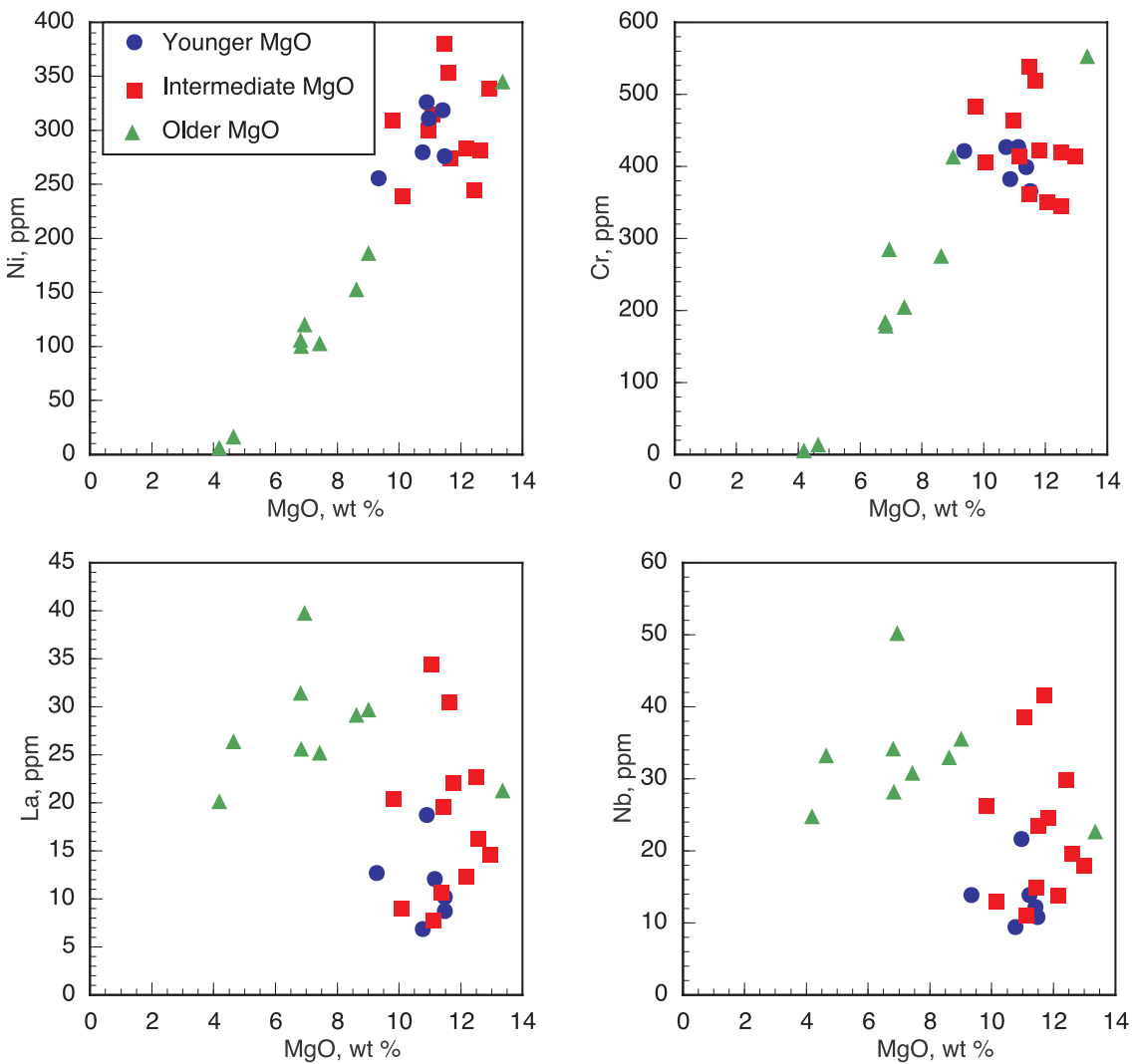

Figure 3. Compatible and incompatible trace elements plotted as a function of $\mathrm{wt} \%$ of $\mathrm{MgO}$. Strong correlations between $\mathrm{Ni}, \mathrm{Cr}$, and $\mathrm{MgO}$ suggest extensive fractional crystallization in the Older Series and less fractional crystallization in the other two series.

St. Paul, and Crozet [Hedge et al., 1973; O'Nions et al., 1977; Dupré and Allègre, 1983; Baxter et al., 1985; Mahoney et al., 1996], as well as to Hawaii. These isotopic data demonstrate that each series has a distinct, and internally heterogeneous, source, with the source for the Older Series being less depleted than those of the Intermediate and Younger Series lavas.

[19] Figure 6 shows variation of $\mathrm{Pb}$ isotope ratios in Mauritius basalts. They exhibit high ${ }^{208} \mathrm{~Pb} /{ }^{204} \mathrm{~Pb}$ and ${ }^{207} \mathrm{~Pb} /{ }^{204} \mathrm{~Pb}$ relative to ${ }^{206} \mathrm{~Pb} /{ }^{204} \mathrm{~Pb}$, which are characteristic of both MORB and OIB from the Indian Ocean (i.e., the "DUPAL" signature). Unlike ${ }^{87} \mathrm{Sr} /{ }^{86} \mathrm{Sr},{ }^{176} \mathrm{Hf} /{ }^{177} \mathrm{Hf}$, and ${ }^{143} \mathrm{Nd} /{ }^{44} \mathrm{Nd}$, the $\mathrm{Pb}$ isotopic compositions of Mauritius basalts extend to both higher and lower values than Réunion basalts, and overlap the Réunion field considerably. (We point out that while there is extensive $\mathrm{Pb}$ isotope data on Réunion, the data are heavily biased toward very young and historical lavas of Piton de la Fournaise [e.g., Vlastélic et al., 2005]. Data from older lavas of Piton de la Fournaise and Piton des Neiges are scarce. It may well be that Réunion will show considerably more variation when a more complete data set becomes available.) Younger Series lavas have the lowest ${ }^{206} \mathrm{~Pb} /{ }^{204} \mathrm{~Pb}$ $($ average $=18.593),{ }^{207} \mathrm{~Pb} /{ }^{204} \mathrm{~Pb}$ (average $=$ 15.563 ), and ${ }^{208} \mathrm{~Pb} /{ }^{204} \mathrm{~Pb}$ (average $=38.611$ ). The Older Series lavas generally have the highest $\mathrm{Pb}$ isotope ratios with average values of ${ }^{206} \mathrm{~Pb} /{ }^{204} \mathrm{~Pb}=$ 19.004, ${ }^{207} \mathrm{~Pb} /{ }^{204} \mathrm{~Pb}=15.604$ and ${ }^{208} \mathrm{~Pb} /{ }^{204} \mathrm{~Pb}=$ 39.1. The $\mathrm{Pb}$ isotopic compositions of Intermediate Series lavas is, for the most part, intermediate between the Older and Younger Series with an average $\mathrm{Pb}$ isotopic composition of ${ }^{206} \mathrm{~Pb} /{ }^{204} \mathrm{~Pb}=$ 18.906, ${ }^{207} \mathrm{~Pb} /{ }^{204} \mathrm{~Pb}=15.578$ and ${ }^{208} \mathrm{~Pb} /{ }^{204} \mathrm{~Pb}=$ 38.985 , but they overlap the fields of the other series considerably and three samples (B-5, B-24, $\mathrm{B}-32$ ) have higher ${ }^{206} \mathrm{~Pb} /{ }^{204} \mathrm{~Pb}$ and ${ }^{208} \mathrm{~Pb} /{ }^{204} \mathrm{~Pb}$ than any Older Series lava. The shift toward more depleted $\mathrm{Sr}, \mathrm{Nd}, \mathrm{Hf}$, and $\mathrm{Pb}$ isotopic signatures from the Older Series to the Intermediate Series is similar to that observed between shield-building tholeiites and posterosional volcanism in Hawaiian volcanoes [e.g., Macdonald and Katsura, 1964; Chen and Frey, 1985; West et al., 1987].

[20] Figure 7 shows the relationships of $\varepsilon_{\mathrm{Nd}}$ and ${ }^{87} \mathrm{Sr} /{ }^{86} \mathrm{Sr}$ to the ${ }^{206} \mathrm{~Pb} /{ }^{204} \mathrm{~Pb}$ ratios in Mauritius 

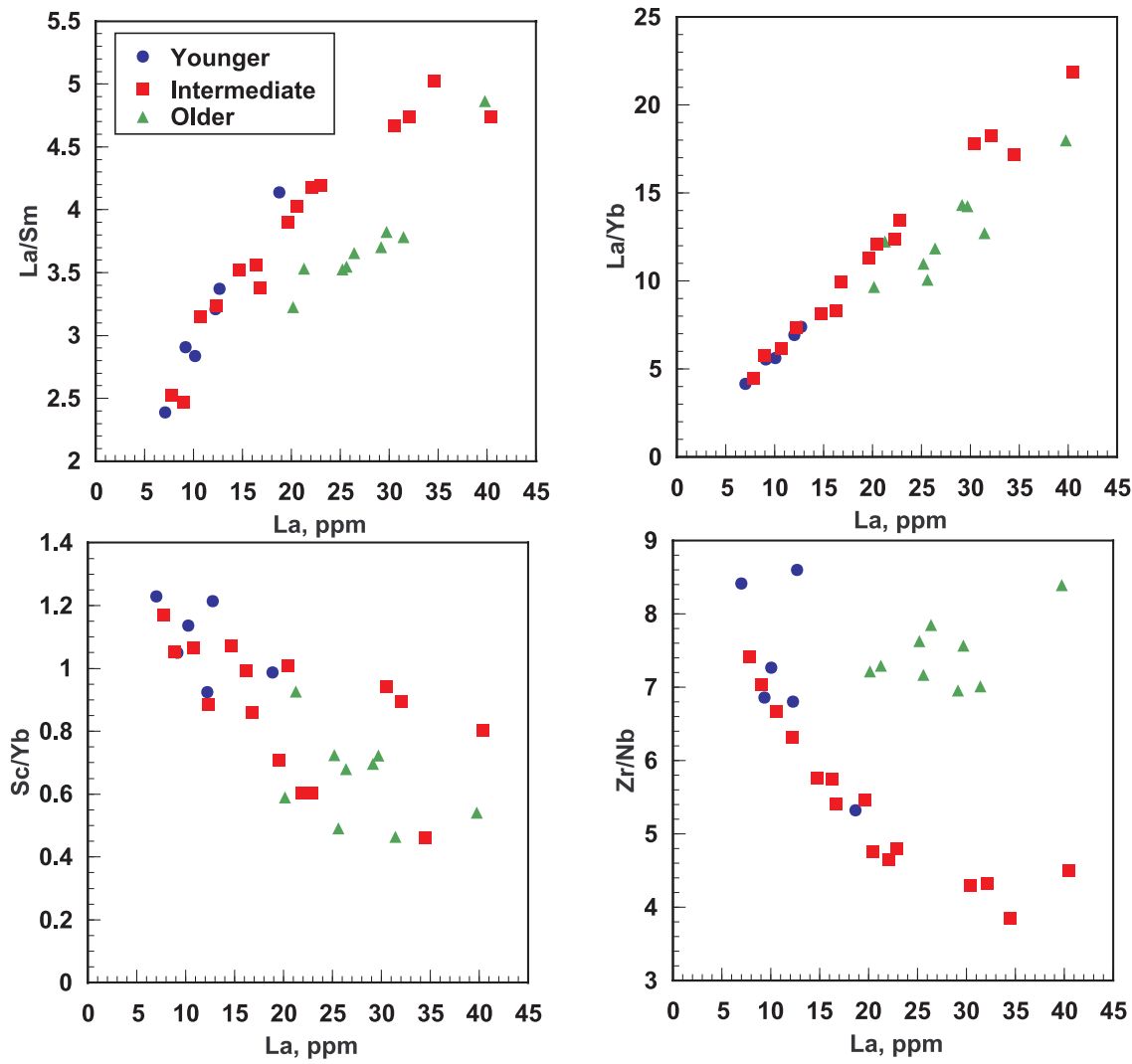

Figure 4. Incompatible element ratios plotted against La concentration in Mauritius lavas. On all plots except $\mathrm{Sc} / \mathrm{Yb}$, the Older Series form a correlation that is distinct from that of the Intermediate and Younger Series. For a given $\mathrm{La}$ concentration, the Older Series has lower $\mathrm{La} / \mathrm{Sm}$ and $\mathrm{La} / \mathrm{Yb}$ and higher $\mathrm{Zr} / \mathrm{Nb}$ ratios than the Intermediate and Younger Series.

lavas. In Figure $7 \mathrm{a}$, the $\mathrm{Nd}-\mathrm{Pb}$ isotope trend in Older and Intermediate Series are collinear with the Central Indian Ridge (CIR) MORB, and plot away from the Réunion field. Isotopic compositions for Younger Series lavas define a distinct field between CIR MORB and Réunion. In the ${ }^{87} \mathrm{Sr} /{ }^{86} \mathrm{Sr}$ versus ${ }^{206} \mathrm{~Pb} /{ }^{204} \mathrm{~Pb}$ plot (Figure $7 \mathrm{~b}$ ) the three different series define distinct fields.

[21] Animations 1 and 2 provide three-dimensional views of the relationships between Sr, $\mathrm{Nd}, \mathrm{Hf}$, and $\mathrm{Pb}$ isotope ratios. These views show that while the 3 Mauritius series have isotopic compositions that are broadly intermediate between those of Réunion and the CIR, they cannot be thought of simply as mixtures between a Réunion and CIR component, even if both endmembers are allowed to be heterogeneous. Furthermore, each of the 3 series occupies a unique region in isotope space. With our data alone, there appears to be essentially no overlap between the series; with the inclusion of the new data of Nohda et al. [2005], there is quite significant overlap between the Younger and Intermediate fields in $\varepsilon_{\mathrm{Nd}^{-}}{ }^{87} \mathrm{Sr} /{ }^{86} \mathrm{Sr}^{206} \mathrm{~Pb} /{ }^{204} \mathrm{~Pb}$ space, but the Older Series remains distinct.

[22] Figure 8 shows the relationship between a variety of trace element ratios and ${ }^{87} \mathrm{Sr} /{ }^{86} \mathrm{Sr}$. There is essentially no correlation between trace element ratios and ${ }^{87} \mathrm{Sr} /{ }^{86} \mathrm{Sr}$. Correlations between trace element ratios and other isotope ratios are similarly poor. Despite having distinctly lower ${ }^{87} \mathrm{Sr} /{ }^{86} \mathrm{Sr}$ than the Older Series, $\mathrm{La} / \mathrm{Sm}$ and $\mathrm{Zr} / \mathrm{Nb}$ ratios of the Younger and Intermediate Series are broadly similar to those of the Older Series. Sm/Nd of the Younger and Intermediate Series are slightly higher on average and $\mathrm{Rb} / \mathrm{Sr}$ ratios slightly lower than in the Older Series. These latter relationships are what one would expect, suggesting that some of the trace element variability reflects source heterogeneity. However, the overall poor correlation between incompatible element ratios and isotopic composition indicates that some other factor, such as the extent of melting, may exert a more impor- 
Table 3. $\mathrm{Sr}, \mathrm{Nd}, \mathrm{Hf}$, and $\mathrm{Pb}$ Isotope Ratios in the Basalts From Mauritius ${ }^{\mathrm{a}}$

\begin{tabular}{|c|c|c|c|c|c|c|c|c|c|}
\hline & ${ }^{87} \mathrm{Sr} /{ }^{86} \mathrm{Sr}$ & $\varepsilon_{\mathrm{Sr}}$ & ${ }^{143} \mathrm{Nd} /{ }^{144} \mathrm{Nd}$ & $\varepsilon_{\mathrm{Nd}}$ & ${ }^{176} \mathrm{Hf} /{ }^{177} \mathrm{Hf}$ & $\varepsilon_{\mathrm{Hf}}$ & ${ }^{206} \mathrm{~Pb} /{ }^{204} \mathrm{~Pb}$ & ${ }^{207} \mathrm{~Pb} /{ }^{204} \mathrm{~Pb}$ & ${ }^{208} \mathrm{~Pb} /{ }^{204} \mathrm{~Pb}$ \\
\hline \multicolumn{10}{|c|}{ Younger Series } \\
\hline M-59 & $0.70399 \pm 1$ & -7.2 & $0.512927 \pm 18$ & 5.6 & $0.283042 \pm 5$ & 9.5 & 18.469 & 15.559 & 38.454 \\
\hline M-63 & $0.70381 \pm 2$ & -9.8 & $0.512907 \pm 16$ & 5.2 & $0.283061 \pm 6$ & 10.2 & 18.619 & 15.552 & 38.581 \\
\hline M-79 & $0.70394 \pm 2$ & -7.9 & $0.512863 \pm 14$ & 4.4 & $0.283035 \pm 6$ & 9.3 & 18.718 & 15.560 & 38.740 \\
\hline M-82 & $0.70389 \pm 2$ & -8.6 & $0.512872 \pm 16$ & 4.6 & $0.283051 \pm 6$ & 9.9 & 18.690 & 15.551 & 38.720 \\
\hline M-84 & $0.70393 \pm 2$ & -8.1 & $0.512871 \pm 18$ & 4.5 & $0.283037 \pm 6$ & 9.4 & 18.585 & 15.591 & 38.677 \\
\hline M-86 & & & $0.512906 \pm 20$ & 5.2 & $0.283047 \pm 6$ & 9.7 & 18.475 & 15.563 & 38.496 \\
\hline \multicolumn{10}{|c|}{ Intermediate Series } \\
\hline B-5 & $0.70369 \pm 2$ & -11.5 & $0.512874 \pm 16$ & 4.6 & $0.283056 \pm 6$ & 10.0 & 19.170 & 15.599 & 39.352 \\
\hline B-19 & $0.70369 \pm 2$ & -11.5 & $0.512953 \pm 16$ & 6.1 & $0.283082 \pm 6$ & 11.0 & 18.849 & 15.583 & 38.880 \\
\hline B-21 & $0.70369 \pm 2$ & -11.4 & $0.512967 \pm 18$ & 6.4 & $0.283077 \pm 8$ & 10.8 & 18.825 & 15.572 & 38.840 \\
\hline B-24 & $0.70371 \pm 1$ & -11.3 & $0.512923 \pm 14$ & 5.6 & $0.283069 \pm 6$ & 10.5 & 19.095 & 15.578 & 39.312 \\
\hline B-25 & $0.70383 \pm 2$ & -9.5 & $0.512893 \pm 16$ & 5.0 & $0.283084 \pm 5$ & 11.0 & 18.848 & 15.566 & 38.871 \\
\hline B-27 & $0.70396 \pm 2$ & -7.6 & $0.512911 \pm 14$ & 5.3 & $0.283093 \pm 7$ & 11.4 & 18.768 & 15.557 & 38.733 \\
\hline B-33 & $0.70377 \pm 2$ & -10.4 & $0.512930 \pm 16$ & 5.7 & $0.283086 \pm 3$ & 11.1 & 19.058 & 15.583 & 39.199 \\
\hline M-20 & $0.70376 \pm 2$ & -10.4 & $0.512882 \pm 18$ & 4.8 & $0.283064 \pm 5$ & 10.3 & 19.064 & 15.584 & 39.297 \\
\hline M-23 & $0.70377 \pm 1$ & -10.3 & $0.512945 \pm 20$ & 6.0 & $0.283077 \pm 3$ & 10.8 & 18.883 & 15.585 & 38.981 \\
\hline M-25 & $0.70374 \pm 1$ & -10.7 & $0.512927 \pm 16$ & 5.6 & $0.283079 \pm 6$ & 10.9 & 18.643 & 15.559 & 38.629 \\
\hline M-67 & $0.70369 \pm 1$ & -11.5 & $0.512938 \pm 20$ & 5.8 & $0.283068 \pm 5$ & 10.5 & 18.560 & 15.558 & 38.577 \\
\hline M-81 & $0.70372 \pm 1$ & -11.0 & $0.512945 \pm 18$ & 6.0 & $0.283084 \pm 5$ & 11.0 & 18.818 & 15.571 & 38.844 \\
\hline \multicolumn{10}{|c|}{ Older Series } \\
\hline M-4 & $0.70413 \pm 1$ & -5.2 & $0.512903 \pm 16$ & 5.2 & $0.283071 \pm 5$ & 10.6 & 18.992 & 15.616 & 39.121 \\
\hline M-18 & $0.70407 \pm 1$ & -6.0 & $0.512907 \pm 14$ & 5.3 & $0.283077 \pm 5$ & 10.8 & 18.922 & 15.588 & 38.983 \\
\hline M-46 & $0.70417 \pm 1$ & -4.6 & $0.512885 \pm 18$ & 4.8 & $0.283031 \pm 4$ & 9.2 & 18.994 & 15.603 & 39.038 \\
\hline M-50 & $0.70425 \pm 1$ & -3.6 & $0.512887 \pm 18$ & 4.9 & $0.283046 \pm 5$ & 9.7 & 19.002 & 15.611 & 39.102 \\
\hline M-53 & $0.70411 \pm 1$ & -5.5 & $0.512901 \pm 18$ & 5.1 & $0.283048 \pm 7$ & 9.8 & 19.082 & 15.624 & 39.167 \\
\hline M-61 & $0.70404 \pm 1$ & -6.5 & $0.512856 \pm 12$ & 4.3 & $0.282997 \pm 6$ & 8.0 & 19.079 & 15.605 & 39.318 \\
\hline M-69 & $0.70409 \pm 1$ & -5.8 & $0.512904 \pm 16$ & 5.2 & $0.283063 \pm 4$ & 10.3 & 19.011 & 15.583 & 39.033 \\
\hline M-70 & $0.70425 \pm 2$ & -3.6 & $0.512889 \pm 18$ & 4.9 & $0.283048 \pm 6$ & 9.8 & 18.946 & 15.604 & 39.068 \\
\hline M-74 & $0.70407 \pm 1$ & -6.1 & $0.512898 \pm 18$ & 5.1 & $0.283045 \pm 5$ & 9.7 & 19.008 & 15.605 & 39.067 \\
\hline
\end{tabular}

${ }^{\mathrm{a}} \mathrm{Sr}, \mathrm{Nd}$, and $\mathrm{Hf}$ isotope ratio errors are 2 standard errors of the mean based on in-run statistics. The 2 standard errors for all the $\mathrm{Pb}$ isotope ratios are $\leq 0.0001$. See section 2 for the error estimates based on the NBS $981 \mathrm{~Pb}$ standard [Todt et al., 1996]. Standard error is given as $(\sigma / \sqrt{n}) / m e a n$, where $n$ is the number of measurements and $\sigma$ is the standard deviation. $\varepsilon_{\mathrm{Nd}}, \varepsilon_{\mathrm{Sr}}$, and $\varepsilon_{\mathrm{Hf}}$ are the fractional deviations, in units of parts per 10,000, from the present-day chondritic bulk Earth ratio, which is taken as 0.512638 for ${ }^{143} \mathrm{Nd} /{ }^{144} \mathrm{Nd}, 0.7045$ for ${ }^{87} \mathrm{Sr} /{ }^{86} \mathrm{Sr}$, and 0.282772 for ${ }^{176} \mathrm{Hf} /{ }^{177} \mathrm{Hf}$.

tant control on trace element composition than source heterogeneity.

\section{Discussion}

[23] The location and timing of Mauritian volcanism imply it is a product of the Réunion mantle plume, which apparently began by producing the Deccan Traps flood basalt event in India around 65-66 million years ago [Mahoney et al., 2002] and is now responsible for current volcanism on Réunion [e.g., Duncan and Richards, 1991; Duncan and Storey, 1992]. The isotope data we report here, along with previously reported isotope data [Norry, 1977; Mahoney et al., 1989; Sheth et al., 2003], support this idea. From analysis of basalts recovered from the Réunion hot spot track on ODP Leg 115, White et al. [1990] concluded that the isotopic composition of the Réunion plume has changed with time, shifting systematically toward more enriched signatures. As Figure 9 shows, the Older Series of Mauritius fit this pattern well, having on average slightly lower ${ }^{87} \mathrm{Sr} /{ }^{86} \mathrm{Sr}$ than the somewhat younger basalts from Réunion. Thus we conclude that the Older Series represent the shieldbuilding phase of Mauritius and were produced by melting of the Réunion mantle plume.

\subsection{Source of Rejuvenescent Magmas in Mauritius and Elsewhere}

[24] The Intermediate and Younger Series fit the plume model considerably less well, being too young and having $\mathrm{Sr}, \mathrm{Nd}$, and $\mathrm{Hf}$ isotopic compositions shifted toward MORB values (Figure 9). The isotope data reported here and in other studies suggest that the Younger and Intermediate Series are products of melting of sources different from that of the Older Series. Their alkalic character 

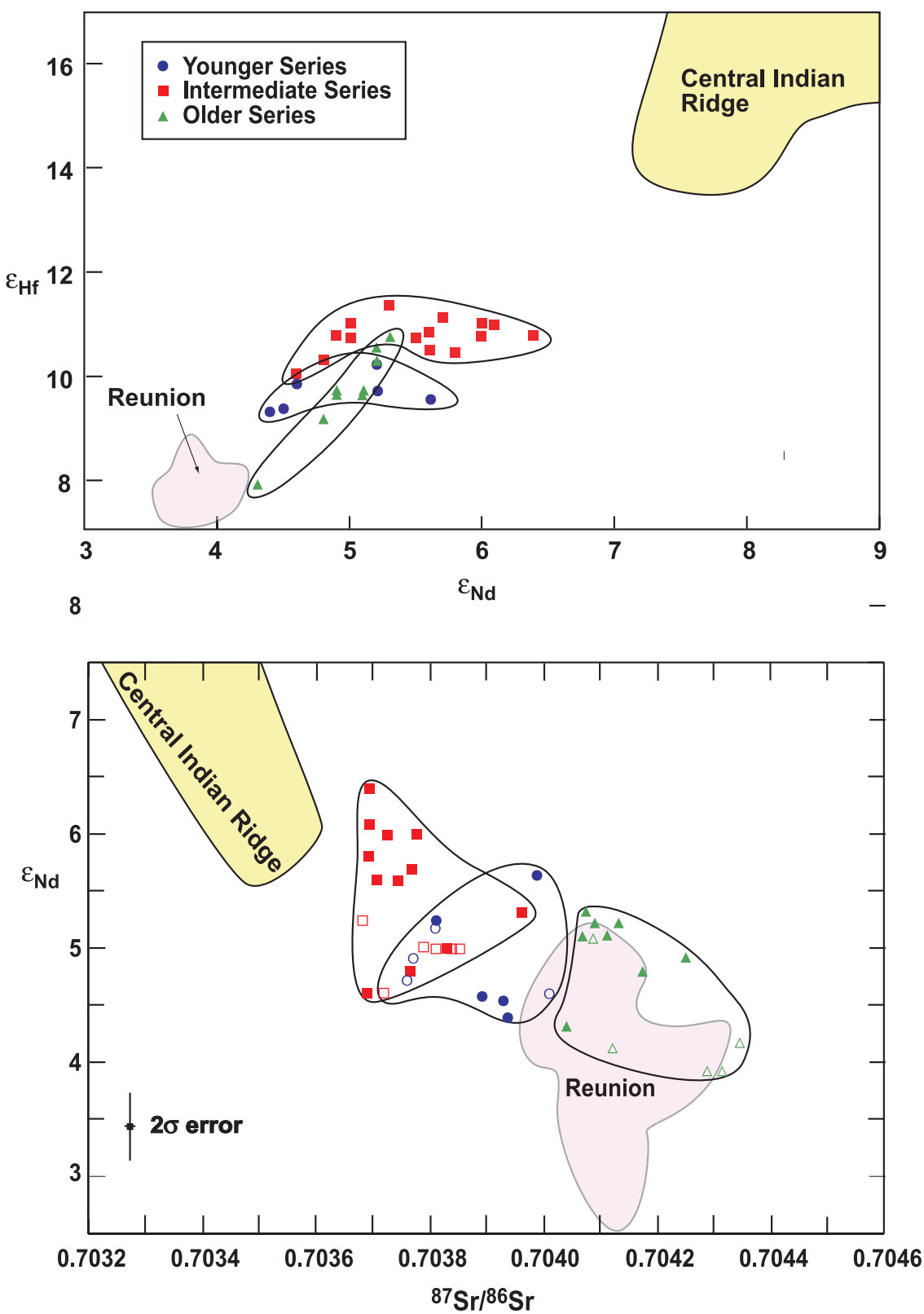

Figure 5. ${ }^{87} \mathrm{Sr} /{ }^{86} \mathrm{Sr}, \varepsilon_{\mathrm{Nd}}$, and $\varepsilon_{\mathrm{Hf}}$ in Mauritius lavas. Shown for comparison are fields for Réunion [Fisk et al., 1988; Albarède et al., 1997; Bosch et al., 1999; Luais, 2004; J. Blichert-Toft, unpublished data] and CIR MORB [Ito et al., 1987; Mahoney et al., 1989; Chauvel and Blichert-Toft, 2001; Escrig et al., 2004]. Open symbols are previously reported data on Mauritius lavas [Mahoney et al., 1989; Peng and Mahoney, 1995; Sheth et al., 2003; Nohda et al., 2005].

suggests they are products of smaller extents of melting than the Older Series, and thus seem analogous to the posterosional series of Hawaii. This raises the questions of what is the source of these lavas and, more profoundly, what is the cause of rejuvenescent volcanism on Mauritius and elsewhere.

[25] There are 3 possible sources of the Younger and Intermediate Series: the mantle plume itself (though a component different from the source of the Older Series), the overlying lithosphere, or surrounding asthenosphere, or a mixture of two or more of these. The idea of a mixed source for rejuvenescent magmas has been a popular one. Chen and Frey [1983] proposed that the source of posterosional volcanism in Hawaii was a mixture of the Hawaiian mantle plume and ambient asthenosphere (i.e., MORB-source). Sheth et al. [2003] suggested that the sources of the Mauritian 

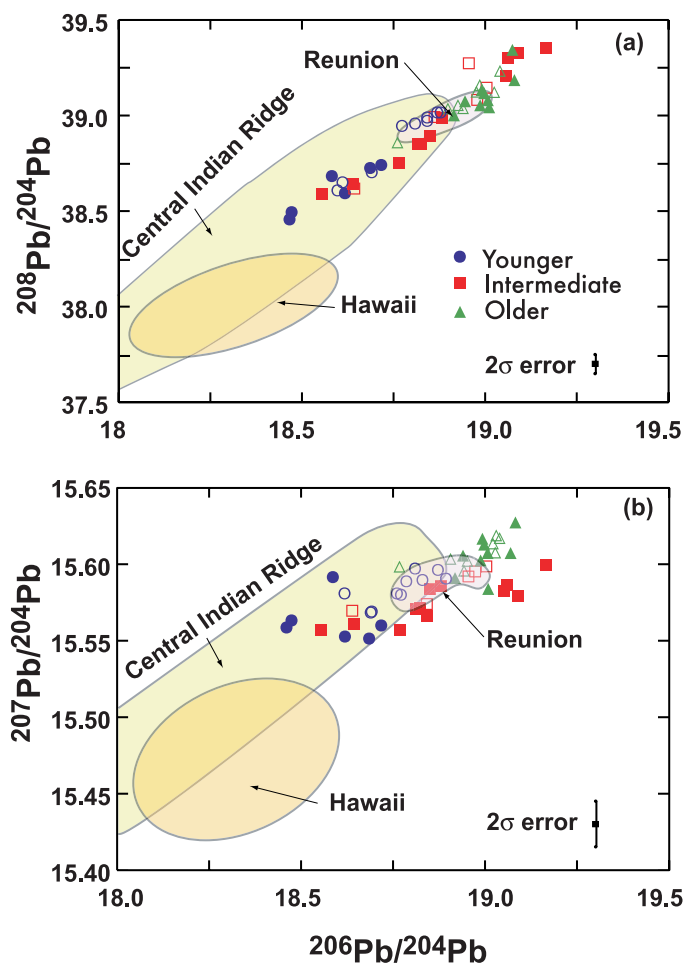

Figure 6. $\mathrm{Pb}$ isotope ratios in Mauritius lavas. Note that the analytical uncertainty for ${ }^{206} \mathrm{~Pb} /{ }^{204} \mathrm{~Pb}$ is smaller than the size of the symbols. Shown for comparison are data from Réunion, Hawaii (GEOROC database, MPI, Mainz), and CIR MORB. Data sources are the same as in Figure 5 except for Réunion, which also includes data from Dupré and Allègre [1983], W. White (unpublished data), and Vlastélic et al. [2005].

volcanics, the Older Series as well as the Intermediate and Younger Series, were mixtures of depleted upper mantle (MORB-source) and an enriched mantle source metasomatized to various degrees by melts derived from depleted upper mantle. Their idea follows an earlier proposal by Roden et al. [1984] to explain Hawaiian posterosional volcanism.

[26] The crust and lithosphere upon which Mauritius was constructed was created at the ancestral CIR at about 50 to $60 \mathrm{Ma}$ [Royer et al., 1992]. We have no samples of Indian MORB of that age, but it seems reasonable to assume that MORB of that age was similar in composition to modern Indian Ocean MORB. This composition presumably represents that of the asthenosphere that melted to produce these basalts and as it cooled, became the lithosphere underlying that crust. Thus a reasonable assumption about the isotopic composition of both lithosphere and asthenosphere beneath Mauritius is that it is similar to modern CIR MORB. One might suppose that the compo- sition of the lithosphere could be altered if it were infiltrated by small degree melts of asthenosphere. However, $60 \mathrm{Ma}$ would not provide the necessary time for $\mathrm{Nd}$ and $\mathrm{Hf}$ isotopic compositions of even highly incompatible-element-enriched metasomatic veins to have evolved to appreciably different values from those of the Indian MORB source. Hence there is no reason to think that either asthenosphere or lithosphere under Mauritius should have isotopic compositions different from modern CIR MORB.

[27] Figures 5-7 and Animations 1 and 2 show that the isotopic compositions of both the Intermediate and Younger Series lavas are distinct from modern CIR MORB; this would seem to rule out both asthenosphere and lithosphere as the source of these lavas. This conclusion is further supported by thermal studies of plumes and their interaction with overlying lithosphere and surrounding asthenosphere. Several such studies have concluded that neither the overlying lithosphere nor the surrounding asthenosphere is sufficiently heated by the plume to melt [Ribe and Christensen, 1994, 1999; Farnetani and Richards, 1995]. The only
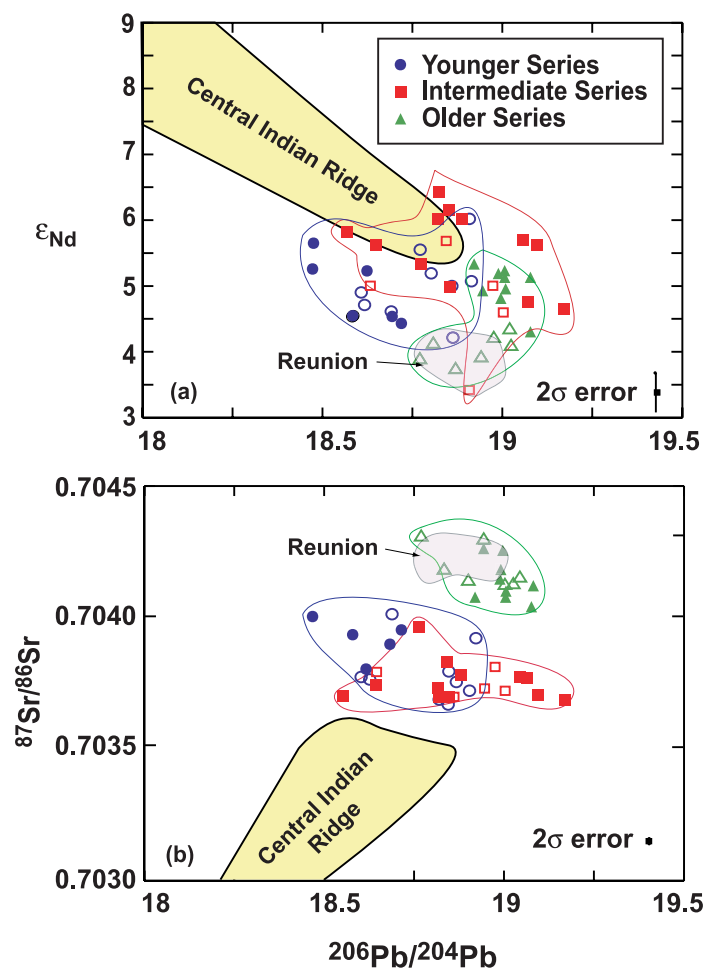

Figure 7. Variations in $\varepsilon_{\mathrm{Nd}}$ and ${ }^{87} \mathrm{Sr} /{ }^{86} \mathrm{Sr}$ with ${ }^{206} \mathrm{~Pb} /{ }^{204} \mathrm{~Pb}$ in Mauritius lavas. Note that in ${ }^{206} \mathrm{~Pb} /{ }^{204} \mathrm{~Pb}-{ }^{87} \mathrm{Sr} /{ }^{86} \mathrm{Sr}$ space the analytical uncertainties are smaller than the symbols plotted. Data sources are the same as in Figures 5 and 6. 


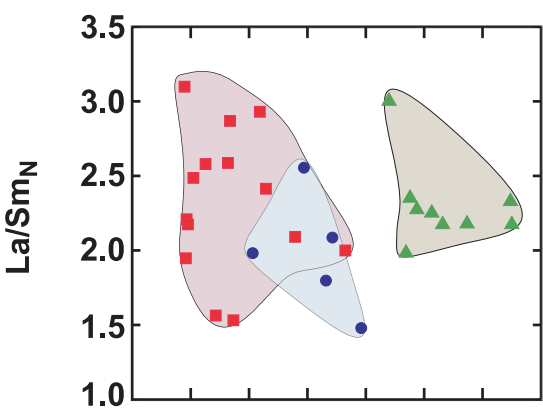

$0.70360 .70380 .7040 \quad 0.7042$

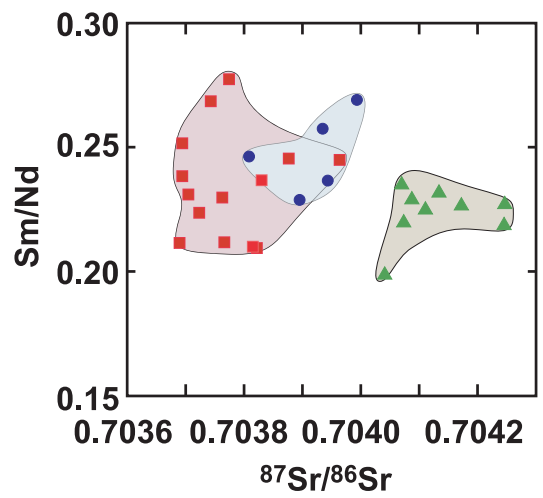

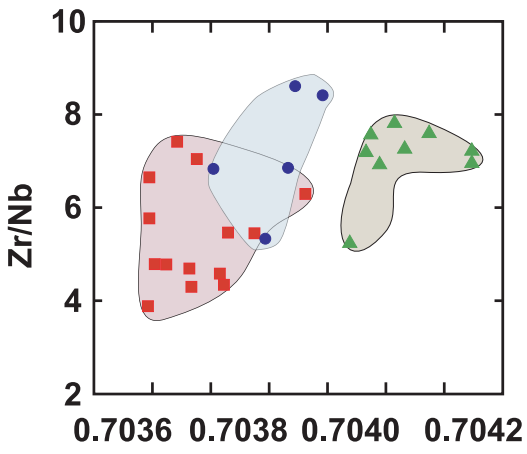

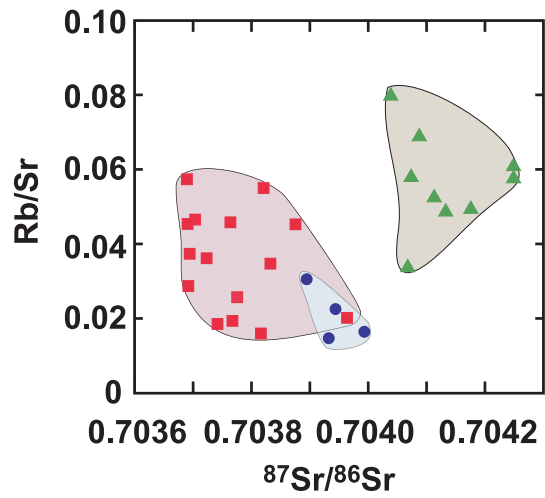

Figure 8. Variations in incompatible element ratios with ${ }^{87} \mathrm{Sr} /{ }^{86} \mathrm{Sr}$ in Mauritius lavas. Symbols are the same as in previous figures. $\mathrm{La} / \mathrm{Sm}_{\mathrm{N}}$ is normalized with respect to chondritic abundances. Correlations are poor overall. The composition of Older Series lavas always plots in a distinct field.

other reason why lithosphere would melt is decompression. Assuming the lithosphere is initially below its solidus, simple thermodynamic calculations show that implausibly large amounts of uplift would be required for lithosphere beneath oceanic islands to undergo sufficient decompression melting $(\sim 1 \%)$ to generate rejuvenescent magmas (if the lithosphere is initially $50^{\circ} \mathrm{C}$ below its solidus, in excess of $15 \mathrm{~km}$ rise would be required to produce $1 \%$ melting). Thus on both chemical and physical grounds, we feel that both lithosphere and asthenosphere can be ruled out as the source of rejuvenescent magmas.

[28] Even if lithosphere and asthenosphere are not the direct source of rejuvenescent magmas, they still might contribute to these magmas. For example, Farnetani and Richards [1995] suggested some lithosphere might be assimilated by magmas rising through it. The general linearity of the data arrays on the $\mathrm{Pb}-\mathrm{Pb}$ isotope plots (Figure 6), particularly ${ }^{208} \mathrm{~Pb} /{ }^{204} \mathrm{~Pb}$ versus ${ }^{206} \mathrm{~Pb} /{ }^{204} \mathrm{~Pb}$, is suggestive of such binary mixing. The scatter could be explained if, as Sheth et al. [2003] propose, either or both end-members are somewhat heterogeneous. This linearity is, however, not present in plots involving $\mathrm{Sr}, \mathrm{Nd}$, and $\mathrm{Hf}$ isotope ratios. In particular, the three-dimensional views of the data afforded by Animations 1 and 2 show that, while the Mauritian rejuvenescent volcanics tend to be intermediate between MORB and both Mauritian Older Series and Réunion, they do not define mixing curves between these, or between any other components for that matter. Indeed, in the Sr-Nd$\mathrm{Pb}$ animation, the fields of the three series are neither linear nor curvilinear. This argues, we believe, against the sources of Mauritian rejuvenescent magmas being binary mixtures of plume and asthenosphere, or of plume and lithosphere.

\subsection{Evaluation of the Ribe and Christensen Model}

[29] If neither lithosphere nor asthenosphere is the source of rejuvenescent magmas, the source can only be within the mantle plume itself. Furthermore, it is difficult to imagine any cause of melting other than decompression. In their model of the Hawaiian plume, Ribe and Christensen [1999] find a weak secondary region of decompression melting within the plume that occurs $300-500 \mathrm{~km}$ downstream from the primary melting zone within the 


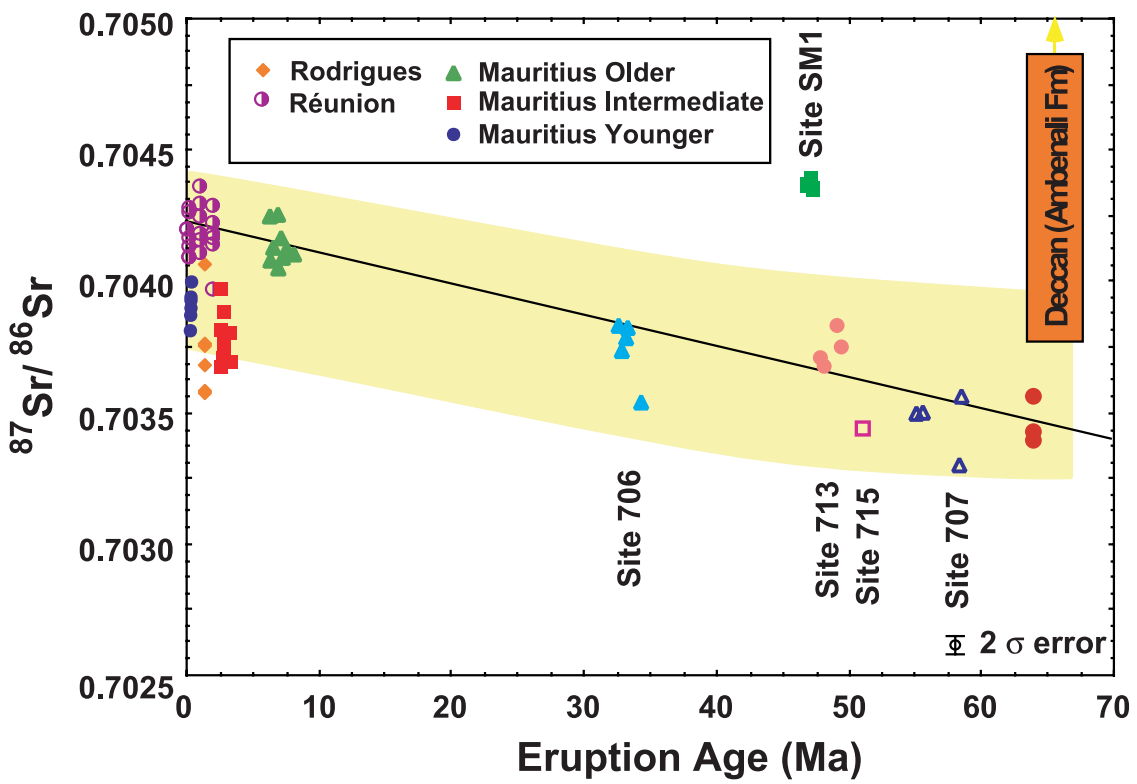

Figure 9. Temporal variation of ${ }^{87} \mathrm{Sr} /{ }^{86} \mathrm{Sr}$ in lavas from Réunion, Mauritius, Rodrigues, the Mascarene Plateau (ODP Leg 115 Sites 706, SM-1, and 707), the Chagos-Lacadive Ridge (Sites 714 and 715), and the Ambenali Formation of the Deccan Flood Basalts $(\sim 65 \mathrm{Ma})$. The Ambenali Formation is thought to represent the least crustally contaminated of the Deccan Flood Basalts. Data are from this study, Baxter et al. [1985], Fisk et al. [1988], White et al. [1990], Albarède et al. [1997], Mahoney et al. [1982], and Lightfoot and Hawkesworth [1988].

vertical stem of the plume. In the model, this secondary melt zone produces a secondary pulse of volcanism about 3.5-5.5 Myr after the initial episode, which agrees well with the timing of rejuvenescent volcanism on many, albeit not all, Hawaiian volcanoes. Melting extents are about $1 \%$, which would produce just the kinds of highly alkaline magmas that typify rejuvenescent volcanism in Hawaii, Mauritius, and elsewhere.

[30] The secondary melting occurs as a consequence of particle paths on the downstream side of the plume. Material in the downstream side of the plume first undergoes limited $(<1 \%)$ melting at the top of the stem of the plume (at depths of 100$110 \mathrm{~km}$ ), but the melting ceases as the rigid lithosphere above prohibits further rise. The material eventually rises slightly again as the plume spreads laterally several hundred $\mathrm{km}$ downstream from the vertical stem. Ribe and Christensen [1999] reported that the secondary melting zone was a robust feature of their model, but Jull and Ribe [2002] subsequently found that its existence was sensitive to boundary conditions. Numerical models of the Hawaiian plume by Phipps Morgan and Parmentier [1998] and Phipps Morgan and Morgan [1999a] produced rather similar patterns of melting as in the Ribe and Christensen model, with melting well downstream of the plume stem as a consequence of buoyant lateral spreading. There is, however, a difference in that Morgan's model has a melting "tail" that extends hundreds of kilometers downstream with no hiatus rather than the discrete "secondary melting zone" that appears in the Ribe and Christensen [1999] model.

[31] The possibility presented in both these models that some particle paths within the plume might lead to melt generation well downstream from the main melting zone provides an appealing explanation of rejuvenescent volcanism, in the Réunion as well as the Hawaiian plume. Although there are key differences between the Réunion-Mauritius situation and Hawaii, such as lithosphere velocity and the buoyancy flux of the plume, that might affect particle paths and therefore the appearance of secondary melting zones, application of these models to Mauritius certainly merits examination.

[32] There are, however, two geochemical problems with these models. First, plume material in the secondary melt region melting tail has already undergone melt extraction in the primary melt region. The extent of extraction is likely small, but can mantle that has already undergone one round of melt removal further melt to generate the highly incompatible-element-enriched magmas that typify rejuvenescent volcanism? Second, if 
Table 4. Partition Coefficients Used in Melting Calculations

\begin{tabular}{lrccc}
\hline & Olivine & Orthopyroxene & Clinopyroxene & Garnet \\
\hline $\mathrm{La}$ & 0.0004 & 0.002 & 0.05 & 0.02 \\
$\mathrm{Ce}$ & 0.0006 & 0.003 & 0.11 & 0.07 \\
$\mathrm{Pr}$ & 0.0008 & 0.0048 & 0.19 & 0.16 \\
$\mathrm{Nd}$ & 0.00093 & 0.0068 & 0.28 & 0.36 \\
$\mathrm{Sm}$ & 0.0013 & 0.01 & 0.40 & 1.00 \\
$\mathrm{Eu}$ & 0.0016 & 0.013 & 0.46 & 1.82 \\
$\mathrm{Gd}$ & 0.0016 & 0.016 & 0.51 & 2.45 \\
$\mathrm{~Tb}$ & 0.0015 & 0.019 & 0.55 & 3.08 \\
$\mathrm{Dy}$ & 0.0016 & 0.022 & 0.60 & 3.20 \\
$\mathrm{Ho}$ & 0.0016 & 0.026 & 0.59 & 3.30 \\
$\mathrm{Er}$ & 0.0016 & 0.03 & 0.58 & 3.40 \\
$\mathrm{Tm}$ & 0.0015 & 0.04 & 0.57 & 3.50 \\
$\mathrm{Yb}$ & 0.0015 & 0.049 & 0.56 & 3.49 \\
$\mathrm{Lu}$ & 0.0015 & 0.06 & 0.55 & 3.40 \\
\hline
\end{tabular}

rejuvenescent magmas originate within the same plume that produced the shield-stage magmas, why are they isotopically distinct?

\subsubsection{Modeling Rare Earths of Secondary Melts}

[33] We address the first question with simple calculations of incompatible element (specifically, the REE) behavior during melting. We assume that the plume is lithologically homogeneous garnet peridotite (6\% garnet, $9 \%$ clinopyroxene, and the remainder olivine and orthopyroxene) and that complete equilibration is achieved (as we shall see, different assumptions must be made to account for isotope ratios). First, we took the Older Series lava with the lowest REE abundances, M74, and calculated a parental magma composition assuming M-74 had experienced 30\% olivine fractionation. Watson and McKenzie [1992] estimate about 7\% melting for production of Hawaiian shield stage magmas. Because the Mauritius Older Series magmas are somewhat more alkalic and because magma production rates for the Réunion plume are lower than for the Hawaiian plume, we assume a somewhat lower extent of melting, 5\%, for production of the Older Series lavas (however, assuming anything in the range from 4 to $7 \%$ makes little difference to the final result). With this assumption, we use this hypothetical parental magma to calculate the source composition using the continuous melting equation [Albarède, 1995] and assuming a porosity of $0.1 \%$. Partition coefficients were drawn from the GERM partition coefficient database (http://earthref.org/GERM) and are listed in Table 4. This is the "primary plume source." As Figure 10 shows, it is slightly enriched in middle rare earths relative to both the light and heavy REE (and has higher-than-chondritic $\mathrm{Sm} / \mathrm{Nd}$, consistent with its positive $\varepsilon_{\mathrm{Nd}}$ ). We then calculated the composition of the secondary source by removing between $0.5 \%$ and $2 \%$ melt fraction from the primary source. Finally, we calculate melt compositions produced by $0.5 \%$ to $2 \%$ melting of this secondary source. The continuous melting model with a porosity of $0.1 \%$ was also used in the latter two melting calculations.

[34] We found that magmas produced by the lowest extent of melting $(0.5 \%)$ of the least depleted secondary source (loss of $0.5 \%$ melt) would have REE abundances and patterns that fall within the range of Mauritian Younger and Intermediate Series lavas (Figure 10). The fit to the Intermediate Series is somewhat better than to the Younger Series, but given all the uncertainties involved, the fit seems reasonable for both series. At higher extents of melting and high extents of depletion of the secondary source, however, the model patterns begin to differ significantly from Younger to Intermediate Series lavas in becoming concave downward in the LREE; i.e., $\mathrm{La} / \mathrm{Ce}_{\mathrm{N}}<1$. This feature, although sometimes seen in other OIB, such as some from Hawaii and the Galapagos, is not present in the rejuvenescent lavas of Mauritius. The turn-over occurs when the melt extraction in the primary melting zone exceeds $\sim 0.5 \%$, or when the extent of melting in the secondary melting zone (generating the rejuvenescent magmas) exceeds $\sim 0.5 \%$. The conditions under which concave downward patterns appear depend somewhat on the melting model used; if the batch melting equation is used, concave downward patterns do not appear until the extent of depletion or degree of melting exceed about $1 \%$; they appear at even smaller extents for pure fractional melting. Increasing the porosity in the continuous melting model allows higher extends of depletion or melting before concave downward patterns appear.

[35] Thus the Ribe and Christensen and Morgan two-stage melting models could produce rejuvenescent-stage magmas with REE abundances and patterns similar to those of Mauritian Younger and Intermediate series lavas, but only if the melt depletion in the primary melting zone is very small $(0.5 \%)$ and the extent of melting in the secondary melting zone is similarly small $(0.5 \%)$. Concave downward rare earth patterns seem to be a characteristic feature of melts produced by two-stage melting models at all except the lowest extents of melting. The absence of such rare earth patterns in 


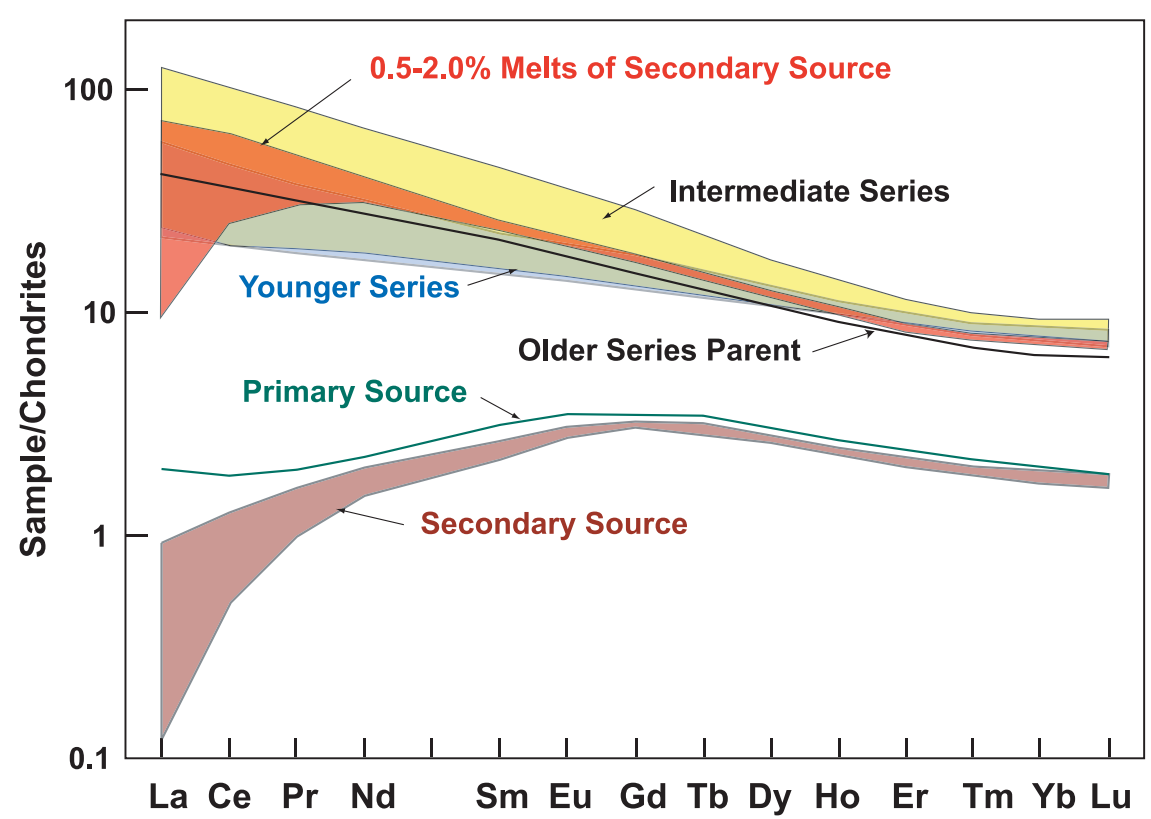

Figure 10. Model of REE patterns for magmas produced by the two-stage melting implicit in the model of Ribe and Christensen [1999]. The "primary source" is calculated assuming that this source produces lava sample M-74 by 5\% melting and 30\% subsequent olivine fractional crystallization. The source is assumed to consist of 58\% olivine, $27 \%$ orthopyroxene, 9\% clinopyroxene, and 6\% garnet. Partition coefficients were compiled from the GERM database (http://earthref.org/GERM/) and are listed in Table 4. Continuous melting [Albarède, 1995] with a porosity of $0.1 \%$ is assumed. The "secondary source" is calculated by removing $0.5-2.0 \%$ melt from the primary source, also by continuous melting. Secondary melts (the rejuvenescent-phase magmas) are then calculated as $0.5-2.0 \%$ melts of the secondary source. Only those melts produced by the lowest extent of melting of the least depleted source match the patterns of Younger and Intermediate Series lavas.

Mauritius, and among rejuvenescent magmas elsewhere, however, raises some doubts about applicability of this model.

\subsubsection{A Lithologically Heterogeneous Plume?}

[36] Isotopic compositions represent a greater difficulty for the Ribe and Christensen and Morgan models. If rejuvenescent magmas originate within the same plume that produced the shield stage magmas, why are they isotopically distinct? One might speculate that the plume is laterally heterogeneous and different parts of the plume contribute to the shield-building and rejuvenescent phases. The problem with this is that rejuvenescent volcanism seems always to have a more depleted isotopic signature than the shield-building stage. This is the case not only in both Hawaii and Mauritius, but in Samoa, and the Society Islands as well. Furthermore, the vast North and South Hawaiian Arch volcanic fields that lie on the seafloor well off to the side of the Hawaiian chain consist of lavas with isotopic signatures that are broadly similar to Hawaiian rejuvenescent magmas. The South Arch is on the up-drift side of the plume, whereas the North Arch is down-drift of the plume. Thus there is simply no reason that the downstream side of a plume should have a more depleted isotopic character than parts of the plume that feed shieldbuilding volcanism. Furthermore, in these models volumes that ultimately melt in the secondary melting zone undergo some melting in the primary melting zone, and thus contribute to shield-building magmas.

[37] The only way that the Ribe and Christensen and Morgan models can account for the isotopic observations is if isotopic equilibration is not achieved during melting such that the isotopic signature of melts somehow depends on extent of melting. This could occur if the plume is both lithologically and isotopically heterogeneous; in other words, it consists of a plum-pudding, marble-cake, or veined mantle in which the veins or plums carry much of the incompatible element inventory as well as the more enriched isotopic signature [e.g., Hanson, 1977; Zindler et al., 1979; Allègre and Turcotte, 1986; Phipps Morgan and Morgan, 1999b]. For example, refractory peridotite 
might be embedded with veins, dikes, pods, or strings of low-solidus material that is somewhat more "basaltic" in composition (e.g., pyroxenite, eclogite, kimberlite). Any small-scale isotopic heterogeneity is likely to be destroyed by diffusional mixing once melting begins [Hofmann and Hart, 1978], but larger scale $(>1 \mathrm{~m})$ heterogeneity might be immune to this as melts of the various components could only be homogenized by advective transport and mixing. Indeed, the observations that melt inclusions are sometimes much more isotopically heterogeneous than their host oceanic island basalts [e.g., Saal et al., 1998] suggest that magma sources are indeed quite heterogeneous on intermediate scales, scales larger than what can be homogenized by diffusion but smaller than the scale of the melting region.

[38] If the Réunion mantle plume is heterogeneous on this scale, both lithologically and isotopically, we speculate that the most isotopically enriched signature, carried in the low-solid veins and pods, might be extracted in Ribe and Christensen's [1999] primary melting region, leaving the more refractory matrix to produce rejuvenescent magmas in the secondary melting zone, or in the melting "tail" of Phipps Morgan and Parmentier [1998] and Phipps Morgan and Morgan [1999a]. At face value, such a model would seem capable of accounting for the more depleted isotopic signatures of rejuvenescent magmas, not only on Mauritius, but also on other oceanic islands such as Hawaii, Samoa, and the Societies. If this model is correct, it is nonetheless surprising that the isotopic compositions of the Younger, Intermediate, and Older Series do not fall along mixing arrays, as it would seem difficult to extract a melt from the "plums" without getting some of the isotopic flavor of the "pudding" or visa versa. This is somewhat troublesome and we have no good explanation for it. In this respect, Mauritius seems somewhat unusual, as isotopic compositions of posterosional lavas from Hawaii, Samoa, and the Societies do form arrays pointing toward the fields for the corresponding shield-stage lavas [e.g., Chen and Frey, 1985; Wright and White, 1987; White and Duncan, 1996]. There is yet another possibility, which is that the more enriched isotopic signature is carried by the most refractory material, which melts only in the higher regions of the primary melting zone. We can think of no observations that allow us to rule out such a scenario; however, it makes less geologic sense. Incompatible-element patterns of oceanic basalts suggest that, ultimately, melting and melt transport is primarily responsible for chemical heterogeneity in the mantle (this is true even in models such as that of Hofmann and White [1982], where subducted oceanic crust carries the enriched isotopic signature). For this reason, we suspect the more enriched isotopic signature should be associated with the least refractory (lowest solidus) material.

[39] A lithologically heterogeneous plume and failure to achieve equilibrium during melting would violate the assumptions we made in modeling REE patterns in the previous section and therefore invalidate the conclusions. If equilibrium is not achieved, and if melt can be extracted from the "plums" without reacting with the surrounding more refractory matrix, the matrix may remain undepleted in incompatible elements before melting in the "melting tail" of Morgan or the "secondary melting zone" of Ribe and Christensen, thus allowing somewhat greater extents of melting in both the primary and secondary melting zone without producing concave downward REE patterns. Whether this is possible depends on the scale of the heterogeneity and how quickly melt flow transitions from compaction-driven porous flow to channelized flow. In porous flow, melt flows along grain boundaries, making both chemical and isotopic equilibrium much more likely than if melt is restricted to veins or dikes. Spiegelman and Kenyon [1992] found that vein spacing of as little as $10 \mathrm{~cm}$ could result in significant disequilibrium. Spiegelman et al. [2001] demonstrated that it is possible for melt migration to transition from porous to channelized flow on length scales comparable to the mantle compaction length $\left(10^{2}-10^{4} \mathrm{~m}\right)$. Their calculations assume a homogeneous medium with the solubility of solid in the melt, a key factor, dependent only on depth. It is unclear just how applicable their calculations are to a lithologically heterogeneous medium. Nevertheless, their results suggest that if the scale of lithologic heterogeneity is greater than the compaction length (i.e., greater than $\left.10^{2}-10^{4} \mathrm{~m}\right)$, it might be possible to extract melt from enriched plums without it equilibrating significantly with the surrounding matrix.

[40] Sleep [1984] pointed out that when low-solidus temperature plums or veins in a more refractory matrix melt, heat will flow from the matrix into the plums and thereby enhance melting of the plums. This occurs because the plums and matrix attempt to maintain thermal equilibrium, yet thermal energy in the plums is being consumed as latent heat of fusion. Hirschmann and Stolper 


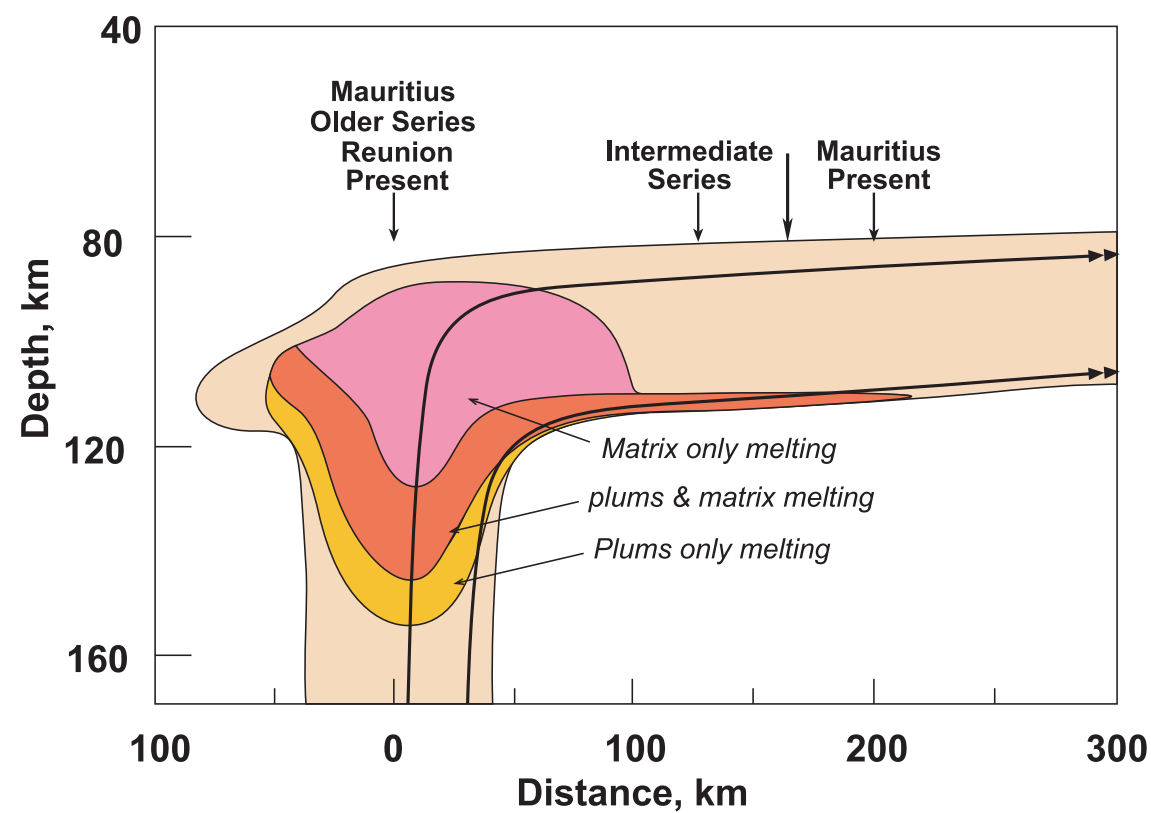

Figure 11. Model of decompression melting in a lithologically heterogeneous plume based on the numerical models of Ribe and Christensen [1999] and Phipps Morgan and Morgan [1999a] and thermodynamic considerations of Phipps Morgan [2001]. Double arrow lines show the flow of material in the core and downstream margin of the plume. The plume is assumed to consist of plums of eclogite or pyroxenite whose solidus is tens of degrees lower than that of the surrounding matrix. Plums begin to melt deep in the interior of the vertical stem of the plume. Thermal energy consumed in melting the plums keeps the matrix from melting until much shallower levels are reached. Plume material then passes into a region where both plums and matrix are melting. Material in the core of the plume eventually reaches a region where only the matrix is melting. Material in the downstream margin passes into the "melting tail," where both plums and matrix are melting. However, the incompatible elements in the plums are effectively all extracted in the vertical stem, so melts generated in the melting tail have the isotopic composition of the matrix.

[1996] and Phipps Morgan [2001] subsequently considered the thermodynamics of this scenario in detail. Phipps Morgan's [2001] analysis reveals that a number of interesting effects can occur. First, melt productivity (i.e., $d F / d P$ ) can be enhanced by a factor of 3 to 5. Second, if the plums are volumetrically significant, then the initial depth of melting of the peridotite fraction will be 5 to $10 \mathrm{~km}$ shallower than otherwise, enlarging the region over which only the plums melt. Third, because the solidus temperature increases as melting proceeds, the solidus temperature of the plums may exceed that of the matrix, so that the plums will stop melting and only the matrix will be melting. In that case, thermal energy flows from the plums to the matrix, enhancing melting in the latter. Consequently, melting in a lithologically heterogeneous plume will be stratified: at the deepest level, only the plums will be melting, at a higher level both plums and matrix will be melting, and finally, only the matrix may be melting. These effects assume that the matrix and plums remain in thermal equilibrium, which in turn limits the scale of heterogeneity to $<100-500 \mathrm{~m}$ [Sleep, 1984; Phipps Morgan, 2001].

\subsection{Model of Volcanic Evolution of Mauritius}

[41] The model we envision is illustrated in Figure 11. The Réunion mantle plume is lithologically heterogeneous with plums of eclogite or pyroxenite embedded in a peridotite matrix. From a consideration of the need to maintain isotopic disequilibrium and thermal equilibrium we deduce that the scale of heterogeneity must be $\sim 10^{2} \mathrm{~m}$. The plum solidus is first reached in the center of the plume, where temperatures are highest. Plum melts rise vertically and mix with melts from the region where both plums and matrix are melting. Provided the plume is hot enough and rises to sufficiently shallow levels, hybrid melts generated at deeper levels will mix at shallower levels with melts generated by melting of only the matrix. These hybrid melts eventually reach the surface as the shield-building lava series (the Older Series 
on Mauritius). Downstream from the plume center, the plum-only melting region pinches out as the plume flattens against the lithosphere, so the melts arriving at the surface are increasingly derived from the plum-and-matrix and matrix-only melting regions. Consequently, the erupted lavas have more depleted isotopic signatures characteristic of late-stage and postshield eruptive phases. Thus our model predicts that stratigraphically controlled geochemical studies on Mauritius, which have yet to be carried out, should reveal that the youngest Older Series lavas should have increasingly depleted isotopic signatures, as they do in Hawaii.

[42] Although the lithosphere deflects the plume horizontally, there is a continued gentle rise of material due to buoyant lateral spreading of the plume [Ribe and Christensen, 1999; Phipps Morgan and Parmentier, 1998; Phipps Morgan and Morgan, 1999a], and consequently continued, albeit very limited, melting on the underside of the plume. Higher up, the plume is already below its solidus due to heat loss to the lithosphere. Melts generated here are from the plums and matrix-melting region and form the rejuvenated stage magmas. Although the plums continue to melt in this region, they contribute little to the incompatible element budget because these elements have been effectively stripped by earlier melting. The radiogenic elements are therefore almost entirely derived from melting of the matrix; hence isotope ratios in the rejuvenated stage lavas reflect isotope compositions of only the matrix.

[43] It may ultimately be possible to test the model we propose by detailed comparison of incompatible element ratios and abundances between shieldstage and rejuvenescent-stage magmas. In our model, a pyroxenite or eclogite-derived melt component should be present in the incompatible element patterns of shield-stage magmas, but absent or nearly absent in rejuvenescent-stage magmas. Stracke et al. [1999] suggested that trace element ratio-isotope ratio correlations provided a test for the presence of pyroxenite-derived components in OIB magmas. They concluded that the correlations observed in Hawaii were inconsistent with predicted correlations for mixing between peridotite- and pyroxenite-derived melts. However, Pertermann et al. [2004] argued that the partition coefficients assumed by Stracke et al. [1999] were inappropriate and concluded that both garnet peridotite and garnet pyroxenite lithologies can induce similar trace element fractionations during partial melting. Thus at present, a straight-forward test is not available.

[44] A final problem arises if plumes have a melting "tail" as in the Phipps Morgan and Morgan [1999a] model rather than a discrete secondary melting zone as in the Ribe and Christensen [1999] model because the former fails to explain the hiatus in volcanism. We speculate that the extent of melting in the melting tail may be too small for melts to actually escape and rise through the lithosphere. Their actual eruption might then require some sort of trigger. There are several possibilities. First, it is possible that erosion of the original shield reduced compressive stresses on the lithosphere to allow melts resident in the melting tail of the plume to migrate through the lithosphere. It is also possible that erosional unloading might have provided sufficient decompression in the plume to enhance the extent of melting in the tail to the points that melts could escape. Jull and McKenzie [1996] and Maclennan et al. [2002] found that eruption rates in Iceland increased 100 fold at the end of the last glacial period (12 kyr BP). Lavas erupted during this period are also poorer in incompatible elements. Jull and McKenzie [1996] and Maclennan et al. [2002] attribute both the higher eruption rates and more depleted nature of the lavas to higher melting rates that occurred as a consequence of unloading of the ice sheet.

[45] The timing of the eruption of the Younger Series, erupted between 0.7 and $0.17 \mathrm{Ma}$, coincides with the construction of volcanic edifices on Réunion. Piton des Neiges appears to have been constructed between 2.0 and $0.43 \mathrm{Ma}$, while construction of Piton de la Fournaise began at about $0.53 \mathrm{Ma}$ [McDougall and Chamalaun, 1969; Gillot and Nativel, 1989]. As the mass of the Réunion volcanoes grew, the lithosphere would have been progressively depressed by the volcanic load and flexural stresses would have developed in response to the load, thereby forming a flexural depression directly under the volcano and a flexural bulge surrounding it. Ten Brink and Brocher [1987] suggested that posterosional volcanism in Hawaii occurs as a consequence of such regional extension and crustal thinning. Watts and ten Brink [1989] argued that construction of the youngest volcano at the end of the chain causes the lithosphere $200 \mathrm{~km}$ downstream of the hot spot to be flexed upward by hundreds of meters. According to ten Brink and Brocher [1987], the consequent extension opens pathways to the surface for melts already present at 
depth. If this same flexure occurred in response to the growth of Piton des Neiges, Mauritius, then located some $170 \mathrm{~km}$ downstream, would have been on or near this bulge. This mechanism might be most appropriate for the Younger Series, which was erupted between 0.7 and $0.17 \mathrm{Ma}$, than the Intermediate Series, erupted between 3.5 and 1.9 Ma, because ages of the former match overlap those of the volcanic edifices on Réunion.

\section{Conclusions}

[46] Older Series volcanism on Mauritius erupted lavas that are isotopically similar to other lavas produced by the Réunion mantle plume, strengthening the relationship between the two. The two subsequently erupted series have isotopic signatures that, while similar to that of Réunion mantle plume products, are more depleted than those of the Réunion plume. Each series exhibits isotopic heterogeneity comparable to the total heterogeneity observed in the two Réunion volcanoes, but the total heterogeneity in Mauritius is substantially greater than observed in neighboring Réunion.

[47] Volcanic evolution on Mauritius, while different in some respects from the Hawaiian pattern, nevertheless bears some important similarities to Hawaii. In both cases, the shield stage terminates with the eruption of differentiated lavas and volcanism is renewed after a period of erosion with eruption of small volumes of highly alkaline lavas with steep REE patterns. In both cases, the late stage lavas exhibit more depleted isotopic signatures than the shield-building stage. Mauritius is different in that following the eruption of the Intermediate Series, large volumes of magma produced by greater extents of melting than the Intermediate Series, resurfaced much of the island.

[48] We suggest that volcanic evolution is controlled by similar processes in Mauritius, Hawaii, Samoa, and the Society Islands. In each case, the main shield is constructed when the volcano is located directly over the core of a lithologically heterogeneous plume that consists of plums of eclogite or other low-solidus-temperature material embedded in a peridotitic matrix. The plums carry a less depleted isotopic signature than the peridotite. In the primary melting zone in the vertical stem of the plume, melting proceeds through plums-only to plums-and-matrix and finally matrixonly stages. Shield-stage magmas are thus hybrid mixtures of melts from the plums and the matrix. Although plums may continue to melt in the secondary melting zone or melting tail located downstream, these plums have been largely stripped of incompatible elements in the primary melting region, so that incompatible elements and isotope compositions in the rejuvenescent-phase magmas reflect that of the peridotitic matrix. Decompression as a consequence of either unloading of the lithosphere as the volcanic edifice erodes or lithospheric flexure related to growth of the next volcano in the chain may contribute to rejuvenescent magmatism by making it easier for magma to ascend to the surface. Our model is similar to that of Phipps Morgan and Morgan [1999a], who proposed that mantle plumes consist of fertile (i.e., rich in a basaltic component and incompatible elements) peridotitic plums embedded in a depleted (in both basaltic component and incompatible elements) peridotitic matrix. In their model, the plums carry the OIB isotopic signature, whereas the matrix has a MORB-like isotope signature. Our model differs from theirs in two respects. First, in theirs, the plums melt to produce OIB, with the matrix melting later to produce MORB, whereas both plums and matrix contribute to OIB magmas in our model. Second, in our model, while the isotopic signature of the matrix is more depleted than that of the plums, it is nonetheless distinct from and less depleted than that of MORB, as are the signatures of rejuvenescent-phase magmas.

\section{Acknowledgments}

[49] This work was supported by NSF award EAR-0079975. J.B.T. acknowledges financial support from the French Institut National des Sciences de l'Univers. We are very grateful to Brian Upton and Martin Fisk for providing samples and major element data. GEOROC, the online database on OIB compositions maintained by the Max-Planck-Institut für Chemie, Mainz, Germany, PETDB, the online database for MORB maintained by Columbia University, and the GERM partition coefficient database maintained by University of California, San Diego were extremely useful in this project. We thank the Water Resources Unit of the Government of Mauritius for providing the most recent geologic map of the island. Interpretation of our data benefited from discussions with Don Turcotte, Jason Phipps Morgan, and John Mahoney. Stagg King assisted with analysis and instrument maintenance at Cornell. The manuscript was improved through careful and constructive reviews by Ivan Vlastélic and John Mahoney.

\section{References}

Albarède, F. (1995), Introduction to Geochemical Modeling, Cambridge Univ. Press, New York.

Albarède, F., B. Luais, J. G. Fitton, M. P. Semet, E. Kaminski, B. G. Upton, P. Bechélery, and J.-L. Chemiee (1997), The geochemical regimes of Piton de la Fournaise volcano 
(Réunion) during the last 530,000 years, J. Petrol., 38, $171-$ 201.

Allègre, C. J., and D. L. Turcotte (1986), Implications of a two-component marble-cake mantle, Nature, 323, 123-127.

Baxter, A. N. (1972), Magmatic Evolution of Mauritius, Western Indian Ocean, Ph.D. thesis, 177 pp., Univ. of Edinburgh, Edinburgh.

Baxter, A. N. (1975), Petrology of the older series lavas from Mauritius, Indian Ocean, Geol. Soc. Am. Bull., 86, 14491458.

Baxter, A. N. (1976), Geochemistry and petrogenesis of primitive alkali basalt from Mauritius, Indian Ocean, Geol. Soc. Am. Bull., 87, 1028-1034.

Baxter, A. N., B. J. G. Upton, and W. M. White (1985), Petrology and geochemistry of the Rodrigues Island, Indian Ocean, Contrib. Mineral. Petrol., 89, 90-101.

Blichert-Toft, J., C. Chauvel, and F. Albarede (1997), Separation of $\mathrm{Hf}$ and $\mathrm{Lu}$ for high-precision isotope analysis of rock samples by magnetic sector-multiple collector ICP-MS, Contrib. Mineral. Petrol., 127, 248-260.

Bosch, D., F. Albarede, and P. Telouk (1999), The Piton de la Fournaise Volcano (Réunion Island, Indian Ocean): Temporal evolution from high resolution $\mathrm{Pb}$ isotopes, J. Conf. Abstr., 4, 345.

Chauvel, C., and J. Blichert-Toft (2001), A hafnium isotope and trace element perspective on melting of the depleted mantle, Earth Planet. Sci. Lett., 190(3-4), 137-151.

Cheatham, M. M., W. F. Sangrey, and W. M. White (1993), Sources of error in external calibration ICP-MS analysis of geological samples and an improved non-linear drift correction, Spectrochim. Acta, 48B, E487-E506.

Chen, C.-Y., and F. A. Frey (1983), Origin of Hawaiian tholeiite and alkalic basalt, Nature, 302, 785-789.

Chen, C.-Y., and F. A. Frey (1985), Trace element and isotopic geochemistry of lavas from Haleakala volcano, east Maui, Hawaii: Implications for the origin of Hawaiian basalts, J. Geophys. Res., 90, 8743-8768.

Deniel, C., G. Kieffer, and J. Lecointre (1992), New ${ }^{230} \mathrm{Th}^{238} \mathrm{U}$ and ${ }^{14} \mathrm{C}$ age determinations from Piton des Neiges volcano, Réunion-A revised chronology for the Differentiated Series, J. Volcanol. Geotherm. Res., 51, 253-267.

Duncan, R. A., and M. A. Richards (1991), Hotspots, mantle plumes, flood basalts, and true polar wander, Rev. Geophys., 29, 31-50.

Duncan, R. A., and M. Storey (1992), The life cycle of Indian Ocean hotspots, Synthesis of Results From Scientific Drilling in the Indian Ocean, Geophys. Monogr. Ser., vol. 70, edited by R. Duncan and D. Rea, pp. 91-103, AGU, Washington, D. C.

Dupré, B., and C. J. Allègre (1983), Pb-Sr isotopic variation in Indian Ocean basalts and mixing phenomena, Nature, 303, $142-146$

Escrig, S., F. Capmas, B. Dupre, and C. J. Allegre (2004), Osmium isotopic constraints on the nature of the DUPAL anomaly from Indian mid-ocean-ridge basalts, Nature, 431, 59-63.

Farnetani, D. G., and M. A. Richards (1995), Thermal entrainment and melting in mantle plumes, Earth Planet. Sci. Lett., 136, 251-267.

Fisk, M. R., B. G. J. Upton, C. E. Ford, and W. M. White (1988), Geochemical and experimental study of the genesis of magmas of Réunion Island, Indian Ocean, J. Geophys. Res., 93, 4933-4950.

Galer, S. J. G., and R. K. O’Nions (1985), Residence time of thorium, uranium, and lead in the mantle with implications for mantle convection, Nature, 316, 778-782.
Gillot, P.-Y., and P. Nativel (1989), Eruptive history of the Piton de la Fournaise volcano, Réunion Island, Indian Ocean, J. Volcanol. Geotherm. Res., 36, 53-65.

Hanson, G. N. (1977), Geochemical evolution of the suboceanic mantle, J. Geol. Soc. London, 134, 235-253.

Hedge, C. E., N. D. Watkins, R. A. Hildreth, and W. P. Doering (1973), ${ }^{87} \mathrm{Sr} /{ }^{86} \mathrm{Sr}$ ratios in basalts from islands in the Indian Ocean, Earth Planet. Sci. Lett., 21, 29-34.

Hirschmann, M. M., and E. Stolper (1996), A possible role for garnet pyroxenite in the origin of the "garnet signature" in MORB, Contrib. Mineral. Petrol., 124(2), 185-208.

Hofmann, A. W. (1988), Chemical differentiation of the Earth: The relationship between mantle, continental crust, and oceanic crust, Earth Planet. Sc. Lett., 90, 297-314.

Hofmann, A. W., and S. R. Hart (1978), An assessment of local and regional isotopic equilibrium in the mantle, Earth Planet Sci. Lett., 38, 44-62.

Hofmann, A. W., and W. M. White (1982), Mantle plumes from ancient oceanic crust, Earth Planet. Sci. Lett., 57, 421-436.

Ito, E., W. M. White, and C. Göpel (1987), The O, Sr, Nd and $\mathrm{Pb}$ isotope geochemistry of MORB, Chem. Geol., 62, 157176.

Jull, M., and D. McKenzie (1996), The effect of deglaciation on mantle melting beneath Iceland, J. Geophys. Res., 101, $21,815-21,825$.

Jull, M., and N. Ribe (2002), The geochemistry of Hawaiian plume dynamics, Geochim. Comsochim. Acta, 81, A375.

Lightfoot, P., and C. J. Hawkesworth (1988), Origin of Deccan Trap lavas: Evidence from combined trace element and Sr-, $\mathrm{Nd}-$, and $\mathrm{Pb}$ isotope studies, Earth Planet. Sci. Lett., 91, 89104.

Luais, B. (2004), Temporal changes in Nd isotopic composition of Piton de la Fournaise magmatism (Réunion Island, Indian Ocean), Geochem. Geophys. Geosyst., 5, Q01008, doi:10.1029/2002GC000502.

MacDonald, G. A., and T. Katsura (1964), Chemical composition of Hawaiian lavas, J. Petrol., 5, 82-133.

Maclennan, J., M. Jull, D. McKenzie, L. Slater, and K. Grönvold (2002), The link between volcanism and deglaciation in Iceland, Geochem. Geophys. Geosyst., 3(11), 1062, doi:10.1029/ $2001 \mathrm{GC} 000282$.

Mahoney, J. J., J. D. MacDougall, G. W. Lugmair, A. V. Murali, M. Shankar Das, and K. Gopalan (1982), Origin of the Deccan Trap flows at Mahalabaleshwar inferred from $\mathrm{Nd}$ and $\mathrm{Sr}$ isotopic and chemical evidence, Earth Planet. Sci. Lett., 60, 47-60.

Mahoney, J. J., J. H. Natland, W. M. White, R. Poreda, S. H. Bloomer, R. L. Fisher, and A. N. Baxter (1989), Isotopic and geochemical provinces of the western Indian Ocean spreading centers, J. Geophys. Res., 94, 4033-4052.

Mahoney, J. J., W. M. White, B. G. J. Upton, C. R. Neal, and R. A. Scrutton (1996), Beyond EM-1: Lavas from AfanasyNikitin Rise and the Crozet Archipelago, Indian Ocean, Geology, 24, 615-618.

Mahoney, J. J., R. A. Duncan, W. Khan, E. Gnos, and G. R. McCormick (2002), Cretaceous volcanic rocks of the South Tethyan suture zone, Pakistan: Implications for the Réunion hotspot and the Deccan Traps, Earth Planet. Sci. Lett., 203, 295-310

McDonald, G. A. (1968), Composition and origin of Hawaiian lavas, in Studies in Volcanology, edited by H. Coats and C. A. Anderson, Mem. Geol. Soc. Am., 116, 477-522.

McDougall, I. (1971), The geochronology and evolution of the young volcanic island of Réunion, Indian Ocean, Geochim. Cosmochim. Acta, 35, 262-288. 
McDougall, I., and F. H. Chamalaun (1969), Isotopic dating and geomagnetic polarity studies on volcanic rocks from Mauritius, Indian Ocean, Geol. Soc. Am. Bull., 80, 1419-1442.

Morgan, W. J. (1981), Hotspot tracks and the opening of the Atlantic and Indian Oceans, in The Sea, vol. 7, edited by C. Emiliani, pp. 443-487, John Wiley, New York.

Nakamura, N. (1974), Determination of REE, Ba, Fe, Mg, Ba, and $\mathrm{K}$ in carbonaceous and ordinary chondrites, Geochim. Cosmochim. Acta, 38, 757-775.

Nohda, S., I. Kaneoka, T. Hanyu, S. Xu, and K. Uto (2005), Systematic variation of $\mathrm{Sr}-, \mathrm{Nd}-$ and $\mathrm{Pb}$-isotopes with time in lavas of Mauritius, Réunion hotspot, J. Petrol., 46, 505-522.

Norry, M. J. (1977), Geochemical studies of volcanics from the Karroo, Mauritius, and Aden volcano, Ph.D. thesis, Univ. of Oxford, Oxford, UK.

O’Nions, R. K., P. J. Hamilton, and N. M. Evenson (1977), Variations in ${ }^{143} \mathrm{Nd} /{ }^{144} \mathrm{Nd}$ and ${ }^{87} \mathrm{Sr} /{ }^{86} \mathrm{Sr}$ ratios in oceanic basalts, Earth Planet. Sci. Lett., 34, 13-22.

Oversby, V. M. (1972), Genetic relations among the volcanic rocks of Réunion: Chemical and lead isotopic evidence, Geochim. Cosmochim. Acta, 36, 1167-1179.

Peng, Z. X., and J. J. Mahoney (1995), Drillhole lavas from the northwestern Deccan Traps, and the evolution of Réunion hotspot mantle, Earth Planet. Sci. Lett., 134, 169-185.

Pertermann, M., M. M. Hirschmann, K. Hametner, D. Günther, and M. W. Schmidt (2004), Experimental determination of trace element partitioning between garnet and silica-rich liquid during anhydrous partial melting of MORB-like eclogite, Geochem. Geophys. Geosyst., 5, Q05A01, doi:10.1029/ 2003GC000638.

Phipps Morgan, J. (2001), Thermodynamics of pressure release melting of a veined plum pudding mantle, Geochem. Geophys. Geosyst., 2(4), doi:10.1029/2000GC000049.

Phipps Morgan, J., and E. M. Parmentier (1998), Three dimensional numerical experiments on plume-lithosphere interaction and restite tectonics, Eos Trans. $A G U, 79(45)$, Fall Meet. Suppl., F1021.

Phipps Morgan, J., and W. J. Morgan (1999a), Is the Hawaiian basalt progression a consequence of progressive melt extraction from the upwelling Hawaiian plume?, J. Conf. Abstr., 4(1), 354 .

Phipps Morgan, J., and W. J. Morgan (1999b), Two-stage melting and the geochemical evolution of the mantle: A recipe for mantle plum-pudding, Earth Planet. Sci. Lett., 170, 215-239.

Ribe, N., and U. Christensen (1994), Three-dimensional modeling of plume-lithosphere interaction, J. Geophys. Res., 99, 669-682.

Ribe, N., and U. Christensen (1999), The dynamical origin of Hawaiian volcanism, Earth Planet. Sci. Lett., 171, 517-531.

Roden, M. F., F. A. Frey, and D. A. Clague (1984), Geochemistry of tholeiitic and alkalic lavas from the Koolau Range, Oahu, Hawaii: Implications for Hawaiian volcanism, Earth Planet. Sci. Lett., 69, 141-158.

Royer, J. Y., et al. (1992), Indian Ocean plate reconstruction since the late Jurassic, Synthesis of Results From Scientific Drilling in the Indian Ocean, Geophys. Monogr. Ser., vol. 70, edited by R. Duncan and D. Rea, pp. 471-475, AGU, Washington, D. C.

Saal, A. E., S. R. Hart, N. Shimizu, E. H. Hauri, and G. D. Layne (1998), $\mathrm{Pb}$ isotopic variability in melt inclusions from oceanic island basalts, Polynesia, Science, 282, 1481-1484.

Sheth, H. C., J. J. Mahoney, and A. N. Baxter (2003), Geochemistry of lavas from Mauritius, Indian Ocean: Mantle sources and petrogenesis, Int. Geol. Rev., 45, 780-797.

Simpson, E. S. W. (1950), The geology and mineral resources of Mauritius, Colon. Geol. Miner. Resour., 1, 217-238.
Sleep, N. H. (1984), Tapping of magmas from ubiquitous mantle heterogeneities: An alternative to mantle plumes, J. Geophys. Res., 89, 10,029-10,041.

Spiegelman, M., and P. Kenyon (1992), The requirements for chemical disequilibrium during magma migration, Earth Planet. Sci. Lett., 109(3-4), 611-620.

Spiegelman, M., P. B. Kelemen, and E. Aharonov (2001), Causes and consequences of flow organization during melt transport: The reaction infiltration instability in compactible media, J. Geophys. Res., 106, 2061-2077.

Stracke, A., V. J. M. Salters, and K. W. W. Sims (1999), Assessing the presence of garnet-pyroxenite in the mantle sources of basalts through combined hafnium-neodymiumthorium isotope systematics, Geochem. Geophys. Geosyst., 1(1), doi:10.1029/1999GC000013.

ten Brink, U. S., and T. M. Brocher (1987), Multichannel seismic evidence for a subcrustal intrusive complex under Oahu and a model for Hawaiian volcanism, J. Geophys. Res., $92,13,687-13,707$

Todt, W., R. A. Cliff, A. Hanser, and A. W. Hofmann (1996), Evaluation of a ${ }^{202} \mathrm{~Pb}^{205} \mathrm{~Pb}$ double spike for high-precision lead isotope analysis, in Earth Processes: Reading the Isotope Code, Geophys. Monogr. Ser., vol. 95, edited by S. R. Hart and A. Basu, pp. 429-437, AGU, Washington.

Upton, B. G. J., and W. J. Wadsworth (1965), Geology of Réunion Island, Indian Ocean, Nature, 207, 151-154.

Upton, B. G. J., and W. J. Wadsworth (1966), The basalts of Réunion Island, Indian Ocean, Bull. Volcanol., 29, 7-24.

Vlastélic, I., T. Staudacher, and M. Semet (2005), Rapid change of lava composition from 1998 to 2002 at Piton de la Fournaise (Réunion) inferred from $\mathrm{Pb}$ isotopes and trace elements: Evidence for variable crustal contamination, J. Petrol., 46, 79-107.

Watson, S., and D. McKenzie (1992), Melt generation in plumes: A study of Hawaiian volcanism, J. Petrol., 32, $501-537$.

Watts, A. B., and U. S. ten Brink (1989), Crustal structure, flexure, and subsidence history of the Hawaiian Islands, J. Geophys. Res., 94, 10,473-10,500.

West, H. B., D. C. Gerlach, W. P. Leeman, and M. O. Garcia (1987), Isotopic constraints on the origin of Hawaiian lavas from the Maui volcanic complex, Hawaii, Nature, 330, $216-$ 220 .

White, W. M., and R. A. Duncan (1996), Geochemistry and geochronology of the Society Islands: New evidence for deep mantle recycling, in Earth Processes: Reading the Isotope Code, Geophys. Monogr. Ser., vol. 95, edited by S. R. Hart and A. Basu, pp. 183-206, AGU, Washington.

White, W. M., and B. Dupré (1986), Sediment subduction and magma genesis in the Lesser Antilles: Isotopic and trace element constraints, J. Geophys. Res., 91, 5927-5942.

White, W. M., M. M. Cheatham, and R. A. Duncan (1990), Isotope geochemistry of Leg 115 basalts and inferences on the history of the Réunion mantle plume, Proc. Ocean Drill. Program Sci. Results, 115, 53-61.

White, W. M., A. R. McBirney, and R. A. Duncan (1993), Petrology and geochemistry of the Galapagos: Portrait of a pathological mantle plume, J. Geophys. Res., 93, 19,53319,563 .

Wright, E., and W. M. White (1987), The origin of Samoa: New evidence from $\mathrm{Sr}, \mathrm{Nd}$, and $\mathrm{Pb}$ isotopes, Earth Planet Sci. Lett., 81, 151-162.

Zindler, A., S. R. Hart, F. A. Frey, and S. P. Jakobsson (1979), Nd and $\mathrm{Sr}$ isotope ratios and rare earth element abundances in Reykjanes Peninsula basalts: Evidence for mantle heterogeneity beneath Iceland, Earth Planet. Sci. Lett., 45, 249-262. 